University of Chicago Law School

Chicago Unbound

Public Law and Legal Theory Working Papers

Working Papers

2012

\title{
When to Overthrow Your Government: The Right to Resist in the World's Constitutions
}

Tom Ginsburg

Daniel Lansberg-Rodriguez

Mila Versteeg

Follow this and additional works at: https://chicagounbound.uchicago.edu/public_law_and_legal_theory

Part of the Law Commons

Chicago Unbound includes both works in progress and final versions of articles. Please be aware that a more recent version of this article may be available on Chicago Unbound, SSRN or elsewhere.

\section{Recommended Citation}

Tom Ginsburg, Daniel Lansberg-Rodriguez \& Mila Versteeg, "When to Overthrow Your Government: The Right to Resist in the World's Constitutions" (University of Chicago Public Law \& Legal Theory Working Paper No. 406, 2012).

This Working Paper is brought to you for free and open access by the Working Papers at Chicago Unbound. It has been accepted for inclusion in Public Law and Legal Theory Working Papers by an authorized administrator of Chicago Unbound. For more information, please contact unbound@law.uchicago.edu. 


\title{
When to Overthrow your Government: The Right to Resist in the World's Constitutions
}

\author{
Tom Ginsburg \\ Daniel Lansberg-Rodriguez \\ Mila Versteeg
}

\begin{abstract}
An On December 17, 2010, a young Tunisian street vendor protesting an abusive police official set off a wave of democratic uprisings throughout the Arab world. In rising up against their governments, the peoples of the Arab countries were confronting an age-old problem in political theory: When is it acceptable to rise up against an unjust authority? This question is not only of great importance to the peoples of the Middle East today but was also of profound interest to the American founders and, through them, has informed the very basis of modern constitutionalism. It is perhaps unsurprising then that many countries' constitutions allow the people to challenge or overthrow their governments under certain circumstances. But to date, little systematic and empirical analysis has been done on the prevalence of this so-called right to resist in national constitutions or on what motivates constitutionmakers to adopt such a right.

This Article takes up the task. It presents an original dataset on right-to-resist provisions in all national constitutions written since 1781, tracing such provisions' historical trajectory and demonstrating how they have proliferated in recent decades. The Article moreover provides the first-ever empirical exploration of why it is, exactly, that constitutionmakers give their people a constitutional mandate to overthrow or contradict their governing authorities-likely those very authorities elsewhere empowered by the same constitution. Drawing on a range of real-world examples as well as regression analysis, we show that right-to-resist provisions are most likely to be first established following a disruption of the previous constitutional order, either through popular democratic transition or through a violent political break such as coup d'état.
\end{abstract}

These findings suggest that the constitutional right to resist serves a dual function, depending on its context. On the one hand, the constitutional right to resist can represent a fundamentally democratic and forward-looking tool that constrains future government abuse, empowers the national citizenry, and acts as an insurance policy against undemocratic backsliding. On the other hand, the right can serve as a backward-looking justification for coupmakers who seek retroactive legitimacy for whatever political crimes placed them in a position to make a new constitution in the first place. Which of these two functions prevails may be in large part regionally determined. Latin American constitutionmakers primarily adopted the right to resist in the aftermath of coups d'etat, while in other parts of the world the right to resist 
functions as a precommitment device against undemocratic backsliding.

Our findings have significant implications for our broader understanding of constitutionalism. Ostensibly, at the heart of any constitution lies a wish to bind the future on behalf of the present. Yet our findings suggest that, at least in some cases, constitutional provisions may also serve the function of reinterpreting and justifying the past. At least as far as the right to resist is concerned, constitutions are as much about yesterday as they are about tomorrow.

\section{AUTHORS}

Tom Ginsburg is Leo Spitz Professor of Law and Ludwig and Hilda Wolf Scholar at University of Chicago Law School and Research Professor at the American Bar Foundation.

Daniel Lansberg-Rodriguez is a Constitutional Research Fellow at the Comparative Constitutions Project and a J.D. Candidate, 2013, at the University of Chicago Law School.

Mila Versteeg is Associate Professor of Law at the University of Virginia School of Law.

The authors would like to thank Moises Dorey, Vahid Gholampour, Trevor Moore, and Benjamin Rohgan for research assistance and Kevin Cope, Denis Galligan, Kelin Gersick, and Laura Weinrib as well as seminar participants at the University of Ljubljana, Slovenia for helpful comments and conversations. 


\section{INTRODUCTION}

On December 17, 2010, a young Tunisian street vendor protesting an abusive police official set off a wave of democratic uprisings throughout the Arab world. ${ }^{1}$ In contrast with externally imposed regime changes in Afghanistan and Iraq, ${ }^{2}$ the long-suffering Arab peoples took it on themselves to drive their former rulers from power and called for a new basis of governance in a region long dominated by dictators. ${ }^{3}$ While the outcomes of these political transitions are still very much in question, they highlighted the importance of popular revolt in bringing about democratic change. ${ }^{4}$

The peoples of the Arab Spring were confronting an age-old problem in political theory: Under what circumstances is it acceptable to rise up against an unjust government? In Bronze Age China, notions of legitimate popular uprisings served as an important potential curb over otherwise formidable imperial authority. ${ }^{5}$ Since then, the same question has plagued or empowered Islamic

1. See Kareem Fahim, Slap to a Man's Pride Set Off Tumult in Tunisia, N.Y. TiMES, Jan. 21, 2011, http:/www.nytimes.com/2011/01/22/world/africa/22sidi.html (describing how, after police officials confiscated his produce, street vendor Mohamed Bouazizi set himself on fire in front of the governor's high gate in protest, which subsequently sparked the revolution in Tunisia as well as the uprisings throughout the Arab states).

2. See, e.g., Zachary Elkins et al., Baghdad, Tokyo, Kabul .... Constitution Making in Occupied States, 49 WM. \& MARY L. REV. 1139, 1141 (2008) (noting that the Iraqi constitution was drafted with "substantial assistance by the U.S. government"); Noah Feldman, Imposed Constitutionalism, 37 CONN. L. REV. 857, 858-59 (2005) (noting that the constitutions of Afghanistan and Iraq were drafted with "substantial intervention and pressure imposed from outside to produce constitutional outcomes preferred by international actors, including NATO, the United Nations, and international NGOs, as well as foreign states like the United States and Germany"). See generally David S. Law \& Mila Versteeg, The Evolution and Ideology of Global Constitutionalism, 99 CALIF. L. REV. 1163 (2011) (finding empirical evidence that constitutions are standardized documents and hypothesizing that this is the result of various types of transnational influence); Benedikt Goderis \& Mila Versteeg, Transnational Constitutions (CentER Discussion Paper Series No. 2013-010) (Apr. 2013), available at http://ssrn.com/abstract=2216582 (finding empirical evidence of transnational influences in constitutional design).

3. See Fouad Ajami, The Arab Spring at One: A Year of Living Dangerously, ForEIGN AFF., Mar.Apr. 2012, at 56, 56, 58 (noting that before the uprisings, the Arabs felt as if "they were cursed, doomed to despotism," and that though Egypt is "[o]ften written off as the quintessential land of political submission," the people throughout the Middle East were able to "[rise] up against their sclerotic masters").

4. See, e.g., Daron Acemoglu \& James A. Robinson, Why Did the West Extend the Franchise? Democracy, Inequality, and Growth in Historical Perspective, 115 Q.J. ECON. 1167, 1167, 1182-86 (2000) (theorizing that western democratization has historically come about through revolution, or at least the threat of a revolution, and that the franchise was extended "as strategic decisions by the political elite to prevent widespread social unrest and revolution").

5. See infra Part III.A (discussing the Chinese tradition and the conceptualization of the right to resist in the works of the philosopher Mencius). 
caliphs, medieval princes, and modern-day despots and democrats in turn. Likewise, for early democratic movements in the eighteenth century, this idea of righteous revolution served as a powerful and unifying raison d'état. ${ }^{6}$ Indeed, the question of when to overthrow government authority was of such profound importance to the American founders that it today stands at the very basis of modern constitutionalism as we know it. ${ }^{7}$

It is perhaps unsurprising then that many constitutions themselves provide a basis for such uprisings. Constitutional provisions allowing individuals to disregard or even attack the governing laws and structures go back at least to the French and American Revolutions. ${ }^{8}$ Their purpose seems to be to remind governors that the people are the ultimate source of legitimate rule and to help diverse populations to coordinate to limit the powers of their rulers.

However, these clauses may also have a dark side. While the language of justified resistance can function to ensure the ultimate enforcement of democracy

6. For examples of how the right to resist featured in early democratic movements in France and America, see, for example, THOMAS JefFerson, To William Stephens Smith, in THOMAS JEFFERSON: POLITICAL WRITINGS 109, 110 (Joyce Appleby \& Terence Ball eds., 1999) ("God forbid we should ever be 20 years without such a rebellion. ... [W] hat country can preserve it's [sic] liberties if their [sic] rulers are not warned from time to time that their people preserve the spirit of resistance? Let them take arms. The remedy is to set them right as to facts, pardon \& pacify them. What signify a few lives lost in a century or two? The tree of liberty must be refreshed from time to time with the blood of patriots \& tyrants. It is it's [sic] natural manure."), 5 JOURNALS OF THE CONTINENTAL CONGRESS, 1774-1789, at 690 (Worthington Chauncey Ford ed., 1906) ("Rebellion to Tyrants is Obedience to God."), and 5 THOMAS PAINE, Dissertation on First Principles of Government, in THE LIFE AND WORKS OF THOMAS PAINE 207, 225 (William M. Van der Weyde ed., 1925) ("It is possible to exclude men from the right of voting, but it is impossible to exclude them from the right of rebelling against that exclusion; and when all other rights are taken away the right of rebellion is made perfect.").

7. See infra Part II (providing a historical overview of the right to resist in different societies, including how this right featured in the thinking of the American founders).

8. See THE DECLARATION OF INDEPENDENCE para. 2 (U.S. 1776) ("That whenever any Form of Government becomes destructive of these ends, it is the Right of the People to alter or to abolish it, and to institute new Government, laying its foundation on such principles and organizing its powers in such form, as to them shall seem most likely to effect their Safety and Happiness. Prudence, indeed, will dictate that Governments long established should not be changed for light and transient causes; and accordingly all experience hath shewn, that mankind are more disposed to suffer, while evils are sufferable, than to right themselves by abolishing the forms to which they are accustomed. But when a long train of abuses and usurpations, pursuing invariably the same Object evinces a design to reduce them under absolute Despotism, it is their right, it is their duty, to throw off such Government, and to provide new Guards for their future security."); DECLARATION OF THE RigHTS OF MAN AND OF THE CITIZEN OF 26 AUGUST 1789 art. 2 (Fr.), translated in 2 MARTINUS NiJHOFF, CONSTITUTIONS OF NATIONS: FRANCE TO NEW ZEALAND 20 (1956) ("The purpose of all civil associations is the preservation of the natural and imprescriptible rights of man. These rights are liberty, property, security, and resistance to oppression."). According to our data, about twenty percent of all constitutions contain such a right today. See infra Figure 1. 
and the defense of the constitution, it can also serve as a justification for earlier unconstitutional acts of resistance. Regimes led by coupmakers such as Jerry Rawlings in Ghana and by alumni of failed coups such as Hugo Chavez in Venezuela have introduced the right to resist in their constitutions. ${ }^{9}$ Clauses of this nature have become increasingly popular as despots and freedom fighters alike have invoked them to justify the past. ${ }^{10}$

Despite the centrality of this so-called right to resist in political theory, we have, until now, possessed little empirical knowledge on the prevalence of this right in national constitutional texts. ${ }^{11}$ As such, we lacked basic information about how many constitutions have adopted the right, whether there are any contextual patterns to adoption, and what (if any) the consequences of that adoption may be. Without this information, we could not even begin to theorize why the right is included in some constitutions and not others.

This Article takes up the task. It presents original data, derived from coding every national constitution written since 1781 , on right-to-resist provisions in global constitutional history. ${ }^{12}$ With this data, this Article traces the development of this right within the world's written constitutions over a 230-year period, and it draws attention to the right's proliferation over the past five decades. It also conducts a textual analysis of all current and historical provisions granting a right to resist, identifying some important variations within the scope, wording, and justifications of such provisions and setting out an analytical framework for classifying them. Our main purpose, however, is to explain why some constitutionmakers would paradoxically give their own people a constitutional mandate to overthrow the very governments they create. Drawing on a range of real-world examples as well as regression analysis, we find that right-to-resist provisions serve a dual function: as both forward-looking promises not to abuse the citizenry and backward-looking justifications for retroactively blessing questionable events that may have led to the constitutionmaking itself. This suggests that the constitution is not only a device for governing the future but also a means for retroactively

9. See infra Part IV.

10. See infra Part III.

11. A note on terminology: We treat the right to rebel and the right to resist as synonymous. No doubt one can distinguish the two, but at their heart, both concepts refer to a right to defend oneself or one's community against unjust assertions of authority. Cf. Tony Honoré, The Right to Rebel, 8 OXFORD J. LEGAL STUD. 34, 36 (1988) (defining the right to rebel as "the right of an individual or group to resort to violence" in order to "secure ... a change in the government," to "resist ... a change in the government," or to secure "the right to independence").

12. See infra Part V (introducing and discussing the new data on the right to resist in constitutions around the world). 
legitimizing a putatively illegal act. Rights to resist are as much about yesterday as they are about tomorrow.

The remainder of this Article proceeds as follows. Part I conceptualizes the basic features of the right to resist in political theory. It shows that the right to resist is commonly perceived as a right of last resort, triggered only in the most extraordinary circumstances of illegitimate government action. It moreover argues that the right to resist is distinct from other rights because of its second-order character. That is, rather than provide a particular substantive limit on state authority, the right to resist serves as an enforcement mechanism to protect other constitutional rights.

Part II traces the history of the right to resist in the political thought of different societies, ranging from ancient China to the American founders to Hobbes and Locke. Part III presents two positive theories that potentially explain why constitutionmakers might include a right to resist in their constitutions. The first theory is that countries adopt this right as a precommitment that enables citizens to coordinate against illegitimate government authority. In this capacity, the right to resist is a fundamentally forward-looking device that imposes constraints on future government action. We expect that countries are particularly likely to embrace such a forward-looking precommitment device during democratic transitions as a potential insurance policy against undemocratic backsliding. A second, and potentially more troubling, theory is that coupmakers may adopt the right to resist to justify their actions retroactively. If the current regime came to power through unconstitutional means, then enshrining such a right may legitimize the coupmaker's actions ex post. This produces two competing hypotheses: that the right is adopted by democratic regimes particularly after democratic transitions or that it is adopted in the aftermath of coups d'état.

Part IV presents our original data on constitutional right-to-resist provisions and uses it to document the historical trajectory of this right in the world's constitutions graphically. Through textual analysis of all right-to-resist provisions, the Article documents some important internal dimensions of variation within this right and proposes a framework for classifying such provisions.

Part $\mathrm{V}$ presents an original empirical analysis identifying the conditions under which countries adopt a right to resist. We find that countries are more likely to adopt right-to-resist provisions both during democratic transitions and after coups d'état. This suggests that the right serves to prevent undemocratic backsliding of newly democratic regimes as well as to legitimate ex post the action of coupmakers. When further exploring this somewhat puzzling finding, we find that it is mainly Latin American countries that adopted the right to resist in the 
aftermath of a coup d'état, while in other parts of the world the right to resist is more likely to function as a precommitment device against undemocratic backsliding.

This apparently dual function of the right to resist has significant implications for our understanding of constitutions more generally. Constitutions are typically adopted to bind the future on behalf of the present. ${ }^{13}$ Yet our findings show that they, at least in some cases, also have the important purpose of interpreting, and in some cases justifying, the past. Finally, the conclusion explores the possible consequences of the right to resist in actual constitutional practice.

\section{ThE RIGHTTO RESISTIN POLITICAL THEORY}

The right to resist has a long history in political theory and has been a feature of political thought in different societies, ranging from ancient China to the American founding. Where it has appeared, the right to resist has been tied to the notion that people can legitimately resist their government in certain situations. While the earliest iterations of such rights commonly justified right-toresist provisions on some notion of higher law, ${ }^{14}$ subsequent conceptualizations of the right have had a more diverse array of motivations. In this Part, we unpack the concept and structure of the right to resist and highlight some of its essential elements. In the next Part, we provide a thumbnail history of its underpinnings in various societies.

\section{A. Concept and Structure}

Political theorists typically regard the right to resist as a form of voice exercised by the people in extreme circumstances. It is justified only in cases of considerable legal alienation wherein the law (or its application) differs drastically and systematically from the will of the community at large. ${ }^{15}$ There must be a

13. See STEPHEN Holmes, PASSIONS AND CONSTRAINT: ON THE THEORY OF LiBERAL DEMOCRACY 135 (1995) (discussing how "[a] constitution . . disempowers short-sighted majorities in the name of binding norms"); JED RUBENFELD, FREEDOM AND TIME: A THEORY OF CONSTITUTIONAL SELF-GOVERNMENT 93 (2001) (describing constitutionmaking as "a nation's struggle to lay down and live out its own fundamental political commitments over time").

14. See Edward Rubin, Judicial Review and the Right to Resist, 97 GEO. L.J. 61, 67 (2008) (suggesting that right to resist provisions used to be viewed as a higher form of law that "arises from some source beyond the government's boundaries, binding the ruler as well as its subjects" and "operat[ing] as a control or a constraint upon the ruler").

15. See Roberto Gargarella, The Last Resort: The Right of Resistance in Situations of Legal Alienation, SELA (SEMINARIO ENLATINOAMÉRICA DE TEORÍA CONSTITUCIONAL Y POLÍTICA) PAPERS 1 (2003), http://digitalcommons.law.yale.edu/yls_sela/23 (arguing that in situations in which the law does not represent the will of the community, or "legal alienation," violations of the law are comprehensible and even worthy). 
level of abuse that admits of no alternative path than resistance; the normal channels of voice must not be available or effective. The right to resist is not to be invoked in response to everyday, garden-variety illegalities. ${ }^{16}$ Rather, it is only when the level of injustice becomes truly intolerable, without conventional legal remedy, that resistance can be invoked. ${ }^{17}$

The right to resist is also distinguishable from civil disobedience. ${ }^{18}$ Civil disobedience is nonviolent protest designed to affect particular public policies. In contrast, the right to resist evokes the language of violence. It has as its aims not merely the replacement of particular policies with more desirable ones but the wholesale restructuring of an entire regime. It thus requires a higher threshold of abuse before being invoked, but it also has more severe consequences for the target of protest.

The right to resist is sometimes an individual right and sometimes a collective one. Tony Honore distinguishes three different situations for exercise of the right, all of which involve a permissible resort to violence. ${ }^{19}$ The right can be exercised on behalf of the oppressed to change government, which he calls "radical rebellion"; it can be used to resist a change in government that the rulers seek to bring about, which he calls "conservative rebellion"; or it can be used to secure independence, as in the right to self-determination. ${ }^{20}$ In the case of the former two situations, individuals and collectivities may invoke the right if the individuals have suffered the requisite forms of oppression. In contrast, the selfdetermination category requires that an individual possess membership in a defined collectivity prior to exercising the right. ${ }^{21}$

Note that effectively exercising the right to resist does not require a fully articulated alternative program. The exercise of the right is a critique of the current regime, but it is no defense of the regime to say that resisters have no specific plans for a replacement. This point sheds light on some of the current debates surrounding the Occupy Wall Street movement, which has at times

16. See Arthur Kaufmann, Small Scale Right to Resist, 21 NEW ENG. L. REV. 571, 574 (1985-1986) (explaining that the right to resist should be considered an emergency right and used only in extremely exceptional situations).

17. See id. ("Resistance may be considered only subsidiary, to wit, when and if all legal and peaceful remedies have been exhausted.").

18. See Gargarella, supra note 15, at 2-4 (outlining the similarities and differences between civil disobedience and what Gargarella calls "constitutional resistance"); see also CONSTITUTION OF DEC. 1992 [NIGER], § 6 (providing for a right to resist through civil disobedience).

19. Honoré, supra note 11 , at 36 .

20. Id. at 36-37.

21. Id. at 37 ("An individual cannot by himself have a right to self-determination, but he may have a right to rebel by virtue of his membership of a group (e.g. Palestinians) which has such a right."). 
invoked the right to resist in justifying its actions. ${ }^{22}$ One line of criticism is that the movement lacks coherent demands or a positive political program. But this critique is irrelevant in terms of the right to resist per se. The only predicate for justified resistance is abuse by the authorities that rises to a certain high level.

The right to resist, according to some scholars, can also be differentiated from the right to revolution. In Professor Arthur Kaufmann's formulation, the right to resist does not excuse every behavior and requires a degree of proportionality in its exercise. ${ }^{23}$ Otherwise the right is not merely that of resistance but of revolution. The right to resist, as opposed to a right of revolt, has as its goal a restoration of a constitutional order, not its complete displacement. It does not seek to replace the normative standard for guiding future behavior of rulers, but seeks simply to enforce it. The right to resist, in its purest form, is about centering the pieces on the chessboard of governance, not about fundamentally changing the game itself: It calls for a return to normal.

\section{B. Second-Order Character}

The right to resist has a particular structure that distinguishes it from other rights claims. Conventional theories of rights treat them as justified claims enforceable at law. They are sometimes considered trumps or, in one alternative, optimizing conditions. ${ }^{24}$ Under either view, a right is a justified claim that involves an ability to act in a particular way in the interests of justice.

The right to rebel or to resist unjust policies has a different structure. First, it assumes that there is an external standard against which to judge the behavior of rulers, one that is not incorporated into the right itself. This may in turn depend on an exogenously defined principle or else on considerations of the "constitutional order" rather than on the authority of the ruling regime itself. ${ }^{25}$ Rather

22. See, e.g., Endorsement of the Declaration of Occupy Wall St. by Occupy Dayton on April 21, 2012, OCCUPY DAYTON (June 11, 2012), http://www.occupydaytonoh.org/archives/1893 ("We recognize that our nation articulated a dream of political democracy in 1776 and established the right to rebel against tyranny.") (emphasis added).

23. See Kaufmann, supra note 16.

24. See Robert AleXY, A TheOry OF CONSTITUTIONAL Rights (Julian Rivers trans., 2002) (conceptualizing rights as optimizing conditions); Ronald Dworkin, Rights as Trumps, in THEORIES OF RIGHTS 153 (Jeremy Waldron ed., 1984) (conceptualizing rights as trumps over the collective goals of a political action or policy).

25. See, e.g., CONSTITUCIÓN DE LA REPÚBLICA DE HONDURAS Jan. 11, 1982, art. 3, translated in CONSTITUTION OF THE REPUBLIC OF HONDURAS 1982, at 1-2 (Gen. Secretariat, Org. of Am. States ed., 1982) ("No one owes allegiance to a usurping government nor to those who assume office or public service by force of arms or by using means or procedures which violate or ignore the provisions established by this Constitution and other laws. The acts adopted by such authorities are null. The people have the right to resort to insurrection in defense of the constitutional order."). 
than imposing a particular substantive limitation upon rulers directly, the right to resist is a second-order condition, by which other substantive rights are made secure. ${ }^{26}$ For this reason, the constitutional text cannot really be considered the source of the right per se. Rather it is a declaratory provision, recognizing what already exists, which is the constituent authority of the people to serve as ultimate judge of illegal behavior on the part of their rulers. Even if it is not the source of the constraint itself, the inclusion of a right to resist in a constitutional text can facilitate its exercise, for example by stipulating predicate conditions and designating who has the right to invoke it. Properly speaking, however, the textual right to resist only restates what already exists. ${ }^{27}$

Second, the right assumes that the people are the proper enforcers of the constitution. That is, rather than rely on courts or on Madisonian notions of structural constraint, the right to rebel speaks directly to "the people themselves." ${ }^{28}$ This position is consistent with recent work on the enforcement of constitutional democracy. Scholars in recent years have emphasized that it is not the courts that primarily interpret or enforce the constitution; instead, they argue, extrajudicial mechanisms dependent on popular voice are the ultimate sources of constraint. ${ }^{29}$

At the heart of this position lies an implicit optimism. After all, incorporating a right to resist assumes that the people can overcome the staggering mobilization and collective action challenges required for such constitutional enforcement. ${ }^{30}$ As with any endeavor necessitating substantial coordination among many individuals, each beholden to differing moral and political paradigms (to

26. See Honoré, supra note 11, at 38 (describing the right to resist as a remedy that exists where there is a large-scale violation of primary rights).

27. See Heiner Bielefeldt, The Right to Resist, in InTERNATIONAL HANDBOOK OF ViOLENCE RESEARCH 1097, 1103 (Wilhelm Heitmeyer \& John Hagan eds., 2003) (stating that efforts to include the right to resist in positive law are not concerned with constitutionalizing the right but rather "with the formal strengthening of the right to resist, whose existence is already postulated, and defining more precisely the conditions under which it can be exercised").

28. LARry D. Kramer, The PeOPle Themselves: Popular CONSTITUTIONALiSM AND JUDICIAL REVIEW 248 (2004) (arguing that the people themselves, not the courts, are "the highest authority in the land on constitutional law" and that the Supreme Court "is ultimately supposed to yield to our judgments about what the Constitution means").

29. See, e.g., id. at 237-39 (calling into question the assumption that the U.S. Congress cannot be trusted to resolve constitutional issues in place of the Court); JEREMY WALDRON, LAW AND DISAGREEMENT 305 (1999) (arguing against judicial review and presenting a legislative "model of opinionated disagreement" as a replacement, in which "men and women of high spirit argue passionately and vociferously about what rights we have, what justice requires, and what the common good amounts to, motivated in their disagreement not by what's in it for them but by a desire to get it right").

30. See Mancur Olson, The logic of Collective Action: Public Goods And the THEORY OF GROUPS 2 (1971) (explaining that unless there is "coercion or some other special device" to help people take action as a group, "rational, self-interested individuals will not act to achieve their common or group interests"). 
say nothing of personal incentives), the exercise of the right to resist would be difficult under the best of circumstances. An inability to agree on the predicate conditions for triggering the right to resist would likely exacerbate these collective action problems to the point that the right itself would become irrelevant in practice. Even once these triggers are agreed on, the people must also be able to coordinate the timing of resistance- a point that we return to below. ${ }^{31}$

A third distinct feature of the right to resist is that it involves actions that, under normal circumstances, are viewed as illegal or reprehensible. ${ }^{32}$ In this sense, it is a kind of right to do wrong. ${ }^{33}$ It has this in common with the law of just war, in which acts normally considered criminal are justified by reference to the larger aim they serve. ${ }^{34}$ Like just war, it gives rise to the question of whether there is a corresponding duty on the part of the target of justified violence to refrain from responding. Presumably, if the right to resist is properly exercised, the state has a duty not to repress those engaged in it. Such repression might conceivably lead to criminal liability, either on the international plane or in local courts after a political transition, on the part of state agents that engage in such repression.

\section{THE RIGHTTO RESISTIN HISTORICAL PERSPECTIVE}

As discussed in the previous Part, the core premises of the right to resist in political theory include the idea that there exists an external standard against which to judge the behavior of rulers, and the notion that the people themselves are the proper instrument for enforcing this standard. In this Part, we examine the evolution of the right to resist in various traditions of political and religious thought, from ancient China to the American founders.

31. See infra Part III.

32. Honoré, supra note 11, at 36 (noting that the right to resist "is a right to commit acts which are almost certainly unlawful and probably criminal by the standards of the state against which the rebellion is directed" and may consist of acts such as "shooting people or planting bombs").

33. See JEREMY WALDRON, $A$ Right to Do Wrong, in LibERAL Rights: COLLECTED PAPERS 1981-1991, at 63, 63 (1993) ("[I]f we take the idea of moral rights seriously, we have to countenance the possibility that an individual may have a moral right to do something that is, from the moral point of view, wrong.").

34. See William V. O’Brien, The CONDUCt OF Just AND Limited WAR 14 (1981) (discussing permissible war as an "exceptional" action requiring objective justification). 


\section{A. The Chinese Tradition}

The Confucian political-legal tradition is a diverse one, whose classical sources are traced to the five centuries before the rise of the Common Era. ${ }^{35}$ The Confucian tradition featured a natural law concept of normative ethical standards which apply to all- the $l i .^{36} \mathrm{Li}$ originally referred to specific rituals but came to refer more broadly to behaviors that each person should observe according to his or her role. ${ }^{37}$ Because of its emphasis on the distinct duties associated with particular roles, the standards for rulers were qualitatively different from those for ordinary men. But standards they certainly were, against which external behavior could be measured. ${ }^{38}$ Indeed, this is one reason that the Confucian tradition glorified abdication in favor of a wise successor rather than hereditary rule. ${ }^{39}$

Within Confucian thought, the idea of a right to resist that inhered in the people is typically associated with Mencius. ${ }^{40}$ Mencius was a Chinese philosopher who glorified the sage-king ideal and championed the notion of the Mandate of Heaven. ${ }^{41}$ Rulers would enjoy the Mandate of Heaven so long as

35. See generally RONNIE L. LITTLEJOHN, CONFUCIANISM: AN INTRODUCTION, at xix (2011) (describing Confucianism as "the great Chinese tradition that has gathered around the teachings of Confucius (Kongzi) for over 2,500 years" and as an "ancient and immense tradition of great subtlety and complexity").

36. See id. at 27 (describing how Confucius taught that the $l i$ are rites that "include the behaviors that indicate moral appropriateness and cultured decorum in relationships and ceremonies"); KWONGLOI SHun, MENCIUS AND EARLY CHINESE THOUghT 24 (1997) (stating that $l i$ originally referred to "rites of sacrifice" and later grew to encapsulate "not just ceremonial behavior but behavior appropriate to one's social position," but was still frequently used to refer to "rules of conduct governing ceremonial behavior").

37. See Chaihark Hahm, Ritual and Constitutionalism: Disputing the Ruler's Legitimacy in a Confucian Polity, 57 AM. J. COMP. L. 135, 144 (2009) ("[T] he idea of li came to lose much of its religious overtones. ... [I]t began to refer to the proper way of performing a certain task. The task at hand might be such formal ceremonies as weddings, funerals, or coronations, but it could also include relatively more informal matters like writing a letter or even addressing a person in everyday conversation." (footnote omitted)).

38. See Tom Ginsburg, Confucian Constitutionalism? The Emergence of Constitutional Review in Korea and Taiwan, 27 LAW \& SOC. INQUIRY 763, 766-67 (2002) (observing that under Confucian tradition Chinese emperors had a duty to rule in an ethical and moral fashion and to see to the welfare of the people); Hahm, supra note 37 , at 150 (noting that Confucian rituals, or $l i$, "could be used to legitimize the power of the ruler as well as to censure and discipline the ruler").

39. See Sungmoon Kim, Confucian Constitutionalism: Mencius and Xunzi on Virtue, Ritual, and Royal Transmission, 73 REV. POL. 371, 377 (2011) (noting that abdication was preferable to hereditary rule of inferior kings).

40. DenNis BlOODWORTH, THE CHINESE LOOKING GLASS 30 (1967) (stating that Mencius established the "principle of popular revolt" when he remarked on the murder of the last king of the Shang dynasty: "I have heard that a fellow called Jou was put to death, but not that a sovereign was killed" (internal quotation marks omitted)).

41. See id. (describing Mencius's conception of the Mandate of Heaven); FUNG YU-LAN, A HISTORY OF CHINESE PHILOSOPHY: THE PERIOD OF THE PHILOSOPHERS (FROM THE BEGINNINGS 
they behaved properly. If they failed to observe the $l i$, however, they might lose the Mandate of Heaven, and this would be reflected in the rise of natural disasters, wars, or economic difficulties. ${ }^{42}$

The theory of the Mandate of Heaven helped scholars to understand the rise and fall of rulers, and it is sometimes identified with a right of rebellion. But properly speaking, Mencius identified heaven, not the people, as the source of constraint. The people's behavior reflected the will of heaven but did not constitute an independently exercised agency. ${ }^{43}$ This has led to some recent revision of the view that Mencius was truly supportive of laypeople's right to rebel. ${ }^{44}$ It is likely that he distinguished a right of protest from a true right of rebellion, which implies an ability to replace the ruler with a new one. The current view is that exclusively noble families held this latter right. ${ }^{45}$ Still, there is consensus that there was some concept of justified resistance to commands of the rulers, and later scholars discussed this. ${ }^{46}$

Ultimately, the Mencian tradition within Confucian thought was sublimated for a number of reasons. ${ }^{47}$ The ruling class may have feared the possibilities associated with implied agency on the part of the people. Rulers certainly preferred the notion of hereditary rule to the idea that only sage-kings could

TO CIRCA 100 B.C.) 117 (Derk Bodde trans., 1937) ("In Mencius's ideal government, ... the ruler of the empire must be a Sage."). Mencius was not the originator of the idea of the Mandate of Heaven, but he was a staunch supporter of the concept. See LITTLEJOHN, supra note 35, at 3 (attributing the origin of the Mandate to the Duke of $Z$ hou).

42. See BLOODWORTH, supra note 40, at 30 ("[T] he ruler holds a celestial license as long as he rules well, but if he does ill, and another overthrows him and takes his place, it is because a frowning heaven has withdrawn its mandate and conferred it on the newcomer, who is, ipso facto, the better man.").

43. See Kim, supra note 39 , at 380.

44. See Justin Tiwald, A Right of Rebellion in the Mengzi?, 7 DAO 269, 270 (2008) (noting that Mencius suggested "that derelict rulers [could] be justly deposed," but "[took] pains to avoid endorsing [a popular right of rebellion], and even designate[d] a particular member of the ruling class-'Heaven's Delegated Official' . . . - to make crucial decisions about the overthrow of governments on the people's behalf'); see also Kim, supra note 39, at 378, 385, 387 (arguing that Xunzi is the better source for the Chinese doctrine of the right to rebel and that Mencius was focusing on a small set of elites rather than the masses).

45. See Kim, supra note 39, at 385 (arguing that feudal lords or minsters of the noble families with moral virtue possessed the political right to replace the ruler); Tiwald, supra note 44, at 270 (noting that Mengzi designated a member of the ruling class—called "Heaven's Delegated Official" - to decide whether to overthrow the ruler on behalf of the people).

46. See Tiwald, supra note 44, at 269 (mentioning scholars that believed Mencius advocated for resistance to unjust rulers, albeit disagreeing with their assumption that the common people could do the resisting).

47. See H.G. CreEl, ChInESE Thought From Confucius to MaO Tsê-TUNG 166-72 (1953) (discussing Emperor Wu's legalist traits and pointing out that while $\mathrm{Wu}$ adopted Confucianism as the state ideology, in many respects his practices were Confucian in name only); XINZHONG YAO, AN INTRODUCTION TO CONFUCIANISM 52 (2000) (describing how Confucianism modified its documents to gain broader acceptance during the advent of the Han dynasty). 
legitimately rule. Ultimately, the meritocratic system, in which scholar-officials formed the backbone of the regime and its principle constraint, emerged beginning with the Han dynasty in $206 \mathrm{BCE} .{ }^{48}$ Still, in times of trouble and dynastic change, the Mencian tradition could experience revival. The Song dynasty, for example, argued that it had received the Mandate of Heaven and produced an official history of the preceding period that traced the Mandate. ${ }^{49}$ The Chinese tradition thus included the seeds of a right to resist, though the idea did not fully blossom as it did in the era of the French and American revolutions.

\section{B. Jewish and Islamic Religious Thought}

An external standard against which the behavior of government authorities may be evaluated is a feature of any axial legal system in which there is a realm of God and a realm of man. ${ }^{50}$ By definition, the authority of God is superior to that of Caesar, and as such it is common for religiously based legal systems to articulate expressed limits on political authority. ${ }^{51}$ Religious systems, while perhaps limiting an earthly ruler's authority, may well stop short of legitimizing the people as a relevant actor for enforcing these boundaries. After all, if a divinity wants to punish an unjust ruler, she would certainly possess the ability to do so, rendering popular enforcement redundant. Ancient Israelite traditions of remonstrance, for example, never developed into a full-fledged right to resist because they did not address the crucial question of what earthly body could determine when unjust rule reached the level justifying a rebellion. ${ }^{52}$ Likewise, the stoic philosophers

48. See Vitaly A. Rubin, Individual And State In Ancient China: Essays on Four CHINESE PHILOSOPHERS 29-30 (Steven I. Levine trans., 1976) (describing the adoption of Confucianism by the Han dynasty and the establishment of a system of examinations for the recruitment of government officials); Kim, supra note 39, at 372 (noting that a blend of Confucianism and legalism became "firmly institutionalized" and "massively politicized" during the Han dynasty).

49. See F.W. MOTE, IMPERIAL CHINA: 900-1800, at 102 (1999) ("The Song dynasty's founder, Zhao Kuangyin, went to great lengths to be 'correct' (zheng), as the criteria for legitimacy defined correctness, by arranging for the Zhou empress dowager, in the name of her young son, to abdicate in his favor. ... He thus could lay claim to be 'correct,' half of what was required to legitimate the transfer of Heaven's Mandate.").

50. See S.N. Eisenstadt, Introduction: The Axial Age Breakthroughs-Their Characteristics and Origins, in THE ORIGINS AND DIVERSITY OF AXIAL AGE CIVILIZATIONS 1, 8 (S.N. Eisenstadt ed., 1986) (noting that in all axial age civilizations "there emerged the conception of the accountability of the rulers and of the community to a higher authority, God, Divine Law, and the like").

51. See Luke 20:24-25 (New American Standard Bible) ("'Show Me a denarius. Whose head and inscription does it have?' They said, 'Caesar's.' And He said to them, 'Then render to Caesar the things that are Caesar's, and to God the things that are God's.").

52. See, e.g., Rubin, supra note 14, at 69-70 (recounting the story of King David's murder of Uriah the Hittite, where the application of laws to the king was instructed by a prophet whose authority and knowledge came from God). 
thought that tyrannical comeuppance was best brought about through divine, rather than popular, mechanisms. ${ }^{53}$

In this light, it is not surprising that the right to resist does not feature strongly in the Islamic legal tradition. ${ }^{54}$ At the same time, there are some Qur'an verses that do seem to point to limits on the duty to obey temporal rulers. Renowned historian Bernard Lewis identifies two such verses in particular that support the idea of disobeying a ruler that compels a person to do something contrary to divine law. ${ }^{55}$

\section{Western Political Thought}

\section{Medieval Antecedents}

Medieval European political thought saw the gradual evolution of ideas of justified resistance against unjust authority. Some of the thinking was contractual, such as the thirteenth-century British Magna Carta or the sixteenthcentury Polish Henrician Articles ${ }^{56}$ both of which authorized nobles to seize the king's castles if he should fail to observe the terms of their respective written agreements. ${ }^{57}$ Similarly, some early sources, such as the German Sachsenspiegel, treated resistance against unjust authority as a duty, requiring the populace to resist rather than merely empowering them to do so. ${ }^{58}$

53. See F.F. BRUCE, The NeW Testament DOCUMENTS: ARE They Reliable? $113-20$ (5th ed. 1960) (quoting a seventh-century letter from stoic philosopher Mara bar-Serapion in stating, "What advantage did the Athenians gain from putting Socrates to death? Famine and plague came upon them as a judgment for their crime. What advantage did the Jews gain from executing their wise king? It was just after that their kingdom was abolished. God justly avenged these three wise men: the Athenians died of hunger; the Samians were overwhelmed by the sea; the Jews, ruined and driven from their land, live in complete dispersion").

54. Cf. Bernard Lewis, Freedom and Justice in the Modern Middle East, FOREIGN AFF., May/June 2005, at 36, 39-40 (discussing the "quietist" approach to resistance against authority in Islamic tradition).

55. See id. (noting that the verses "there is no obedience in sin" and "do not obey a creature against his creator" create a duty of disobedience).

56. See JACEKJEDRUCH, CONSTITUTIONS, ELECTIONS AND LEGISLATURES OF POLAND, 14931977: A GUIDE TO THEIR HISTORY 88-91 (1982) (discussing the "rokosz" or the notion that the nobility could refuse royal decrees or act against royal authorities should the monarch violate their legitimate rights and privileges).

57. See Honoré, supra note 11, at 42. But cf. id. (noting that later editions of the Magna Carta omitted this clause).

58. See Bielefeldt, supra note 27, at 1098 ("And a man must even resist his king and judge if he does wrong, and even help to fight him by any means, even if he is his kinsman or liege lord. And in so doing he does not breach his duty of loyalty." (quoting the Sachsenspiegel, a legal codebook from the German Middle Ages) (internal quotation marks omitted)). 
Christian scholars in the Middle Ages likewise argued at times for the existence of a right to resist unjust authority. ${ }^{59}$ While the New Testament itself is in some places quite clear about the importance of obeying government authorities, ${ }^{60}$ Thomas Aquinas, for example, held that the overthrow of a tyrannical government was not sedition. ${ }^{61}$ William of Ockham's grounding of papal authority within the General Council of the Roman Catholic Church similarly justified the disciplining of a pope by the broader community. ${ }^{62}$

Subsequent thinkers such as Francisco Suárez grounded the sovereignty of kings in earthly authority rather than in a divine right. ${ }^{63}$ Monarchies, in this view, were produced by people to resolve particular problems. It would thus be acceptable to resist application of an unjust law. ${ }^{64}$ Still, these Christian thinkers did not develop a full-fledged right to resist. Calvinists, themselves severely oppressed by nominally infallible kings, developed their own ideas about unjust authority. ${ }^{65}$ Their practical solutions were limited, but Calvin seems to have at least contemplated a magistrate's duty to resist tyranny and a duty of the faithful to resist infringements on the exercise of religion. ${ }^{66}$ These ideas helped lay the basis for social contract theory and incorporated a proto-notion of resistance,

59. See id. (observing that the question of the legitimacy of resistance and tyrannicide "was the subject of many treatises in the scholastic philosophy of the High and Late Middle Ages").

60. See, e.g., Romans 13:1-2 (New International Version) ("Everyone must submit himself to the governing authorities, for there is no authority except that which God has established. The authorities that exist have been established by God. Consequently, he who rebels against the authority is rebelling against what God has instituted, and those who do so will bring judgment on themselves.").

61. See Bielefeldt, supra note 27, at 1098 (stating Aquinas's position that resistance against a tyrant was not sinful rebellion but "a struggle against unjust dominion-dominion that itself amounted to a rebellion against the law").

62. See Rubin, supra note 14 , at 76 .

63. See David B. Kopel et al., The Human Right of Self-Defense, 22 BYU J. PUB. L. 43, 71-72 (2007) (noting Suárez's belief that "a prince had just power only if the power were bestowed by the people"); Rubin, supra note 14, at 78 (discussing Suárez's argument that political authority was a human creation, not ordained by God, and thus subordinate to the Church and subject to natural law).

64. 2 FRANCISCO SUÁREZ, A Treatise on Laws and God the Lawgiver, in SELECTIONS FROM THREE WORKS OF FRANCISCO SUÁREZ, S.J. 3, 273 (Gwladys L. Williams et al. trans., 1995) ("Neither could the aforesaid remedy of the defect [of jurisdiction] with respect to a subject, reasonably have been applied to those things through which it would have been possible to do away with the right of self defence - springing from the law of nature - again a criminal charge, especially a charge that was so grave; for it would not be permissible that the Emperor should abolish those things which proceed from the natural law." (alteration in original) (citation omitted) (internal quotation marks omitted)).

65. See DaVid T. BALl, The Historical Origins of JUdicial REVIEW, 1536-1803: THE DUTY TO RESIST TYRANNY 7 (2005); Rubin, supra note 14, at 80 ("Calvinist writers argued that ungodly kings, representing the erroneous choice of an ungodly people, must be resisted.").

66. BALL, supra note 65, at 43-54 (describing magistrates' duties and those of the faithful). 
even if not fully conceptualized as a duty or accompanied by an institutional manifestation.

The right to resist became increasingly central to political debate in the sixteenth and seventeenth centuries. The thinkers in this era tended to treat the collective right to resist as grounded in an innate right of human self-defense. For example, while the conventional view is that the great Dutch jurist Hugo Grotius was not much of a supporter of popular resistance, ${ }^{67}$ some scholars believe that he would have supported a qualified right to resist if certain conditions were met. ${ }^{68}$ Samuel von Pufendorf generally treated the supreme authority of a sovereign as superior to all laws but also held that "a People may defend themselves against the extreme and unjust Violence of their Prince." 69 Similarly, Emer de Vattel believed that an oppressive Prince provides "his subjects a legal right to resist him ... in their own defence." ${ }^{70}$

\section{Locke and Hobbes}

The right to resist is a central subject of debate between the Lockean and Hobbesian conceptualizations of social contract theory. For Hobbes, the social contract is complete and replaces prior sources of authority; therefore "there can happen no breach of Covenant on the part of the Soveraigne; and consequently none of his Subjects, by any pretence of forfeiture, can be freed from his Subjection." ${ }^{71}$ That is, once a sovereign is granted authority, he may not be subject to claims of legal violation. Hobbes's notion was rooted in a view that there was no legitimate judge outside the sovereign:

67. See John Neville Figgis, Studies of Political Thought From Gerson to GROTIUS, 1414-1625, at 211 (1907) ("Not only is territorial sovereignty a necessary assumption of International Law, but Grotius goes out of his way to condemn the theory of resistance, to show that by the lex regia popular power is wholly transferred to the prince.").

68. See Peter Borschberg, Grotius, the Social Contract and Political Resistance: A Study of the Unpublished Theses LVI 64 n.188 (N.Y. Univ. Sch. of Law History \& Theory of Int'l Law Series, Working Paper No. 2006/7, 2007), available at http://iilj.org/publications/2006-7borschberg.asp (interpreting Grotius's contention that "he who abuses sovereign power renders himself unworthy of sovereignty, and ceases to be a prince, in consequence of the very act by which he converts himself into a tyrant").

69. SAMUEL PUFENDORF, OF THE LAW OF NATURE AND NATIONS bk. VII, ch. VIII, at 722 (Basil Kennett trans., 4th ed. 1729) (1672).

70. EMER DE VATTEL, THE LAW OF NATIONS, OR, PRINCIPLES OF THE LAW OF NATURE, APPLIED TO THE CONDUCT AND AFFAIRS OF NATIONS AND SOVEREIGNS, WITH THREE EARLY ESSAYS ON THE ORIGIN AND NATURE OF NATURAL LAW AND ON LUXURY bk. II 290 (Béla Kapossy \& Richard Whatmore eds., Thomas Nugent trans., Liberty Fund 2008) (1758).

71. Thomas HobBes, Leviathan 97 (Richard E. Flathman \& David Johnston eds., W.W. Norton \& Co. 1997) (1651). 
[I]f any one, or more of them, pretend a breach of the Covenant made by the Soveraigne at his Institution; and others, or one other of his Subjects, or himselfe alone, pretend there was no such breach, there is in this case, no Judge to decide the controversie: it returns therefore to the Sword again; and every man recovereth the right of Protecting himselfe by his own strength, contrary to the designe they had in the Institution. ${ }^{72}$

There is in this view no right to resist, only a right to disband the social contract and return to the state of nature- a result to be avoided whenever possible. ${ }^{73}$

For Locke, on the other hand, all individuals had natural rights, which they surrendered voluntarily as part of the social contract. ${ }^{74}$ The purpose of society was not merely to avoid the destructive battle of all against all but to protect one's property and other rights inherently valued by human beings. Indeed, for Locke the primary enforcement mechanism of the social contract was the peoples' collective right to legitimately revolt against the government should it violate the terms of the contract. As he put it, "whenever the Legislators endeavour to take away, and destroy the Property of the People, or to reduce them to Slavery under Arbitrary Power, they put themselves in a state of War with the People, who are thereupon absolved from any farther Obedience. ${ }^{75}$ Indeed, in some cases, Locke thought of revolution not as a right but as a duty to prevent tyranny. While neither Locke nor Hobbes anticipated a legalized or judicialized concept of constitutional enforcement, Locke's specification of popular action as an enforcement mechanism for the social contract helped crystallize the intellectual underpinnings of the modern right to resist. ${ }^{76}$

Once the basis for legitimate government is conceived of in contractual terms, the requirement of an external standard for evaluating government authority is met. Blackstone, too, included a right to resist in his listing of natural laws. ${ }^{77}$

72. Id.

73. Id. at 70 ("In such condition ... the life of man [is] solitary, poore, nasty, brutish, and short.").

74. JOHN LOCKe, Two Treatises OF GOVERnMENT 330-31 (Peter Laslett ed., Cambridge Univ. Press 1988) (1690) ("The only way whereby any one devests himself of his Natural Liberty, and puts on the bonds of Civil Society is by agreeing with other Men to joyn and unite into a Community....").

75. Id. at 412 .

76. Locke was writing, of course, in the immediate aftermath of the Glorious Revolution, and some see his work as a contemporaneous justification of it. See JEREMY WALDRON, GOD, LOCKE, AND EQUALITY: CHRISTIAN FOUNDATIONS OF JOHN LOCKE'S POLITICAL THOUGHT 84 (2002); Lois G. Schwoerer, Locke, Lockean Ideas, and the Glorious Revolution, 51 J. HIST. IDEAS 531 (1990) (noting Locke's role in the Glorious Revolution).

77. 1 WiLliam BLACKSTONE, COMMENTARIES *139 ("The fifth and last auxiliary right of the subject, that I shall at present mention, is that of having arms for their defence, suitable to their condition and degree, and such as are allowed by law. Which is also declared by the same statute ... 
All that was needed to instantiate the right was a group of people who were willing to declare its exercise appropriate with regard to a particular tyrant. George III turned out to be the unlucky ruler.

\section{American Founders}

The American founders were enthusiastic proponents of a right to rebel against unjust tyranny. Informed by Locke, they rooted the right to rebel in natural law and saw their own plights as meeting the necessary preconditions to justify revolt. ${ }^{78}$ This is apparent in both the Virginia Bill of Rights and the Declaration of Independence. ${ }^{79}$ In the Declaration, Jefferson notes that the people had first exercised their right of petition, which may be thought of as a predicate for rebellion. It is only through repeated rejection of petitions that King George becomes "[a] Prince, whose character is thus marked by every act which may define a Tyrant, [who] is unfit to be the ruler of a free people." ${ }^{\prime \prime}$ Jefferson deemed rebellion against such absolute despotism as not only a right but also a duty, as had Locke and the Sachsenspiegel before him. ${ }^{81}$

and is indeed a public allowance, under due restrictions, of the natural right of resistance and selfpreservation, when the sanctions of society and laws are found insufficient to restrain the violence of oppression.").

78. See, e.g., Christian G. Fritz, AMErican Sovereigns: The PeOPle AND AMERICA's CONSTITUTIONAL TRADITION BEFORE THE CIVIL WAR 13 (2008) (noting that, following Locke's suggestion that "the right of revolution arose only under the most dire circumstances," the American founders saw revolution as "the last-ditch effort of an oppressed people" and "an expression of 'the law of nature"); Samuel West, On the Right to Rebel Against Governors (Election Day Sermon), in 1 AMERICAN POLITICAL WRITING DURING THE FOUNDING ERA, 1760-1805, at 410, 419-20 (1983) ("[B]y the law of self-preservation, which is the first law of nature, they have not only an undoubted right, but it is their indispensable duty, if they cannot be redressed any other way, to renounce all submission to the government that has oppressed them, and set up an independent state of their own ....").

79. THE DECLARATION OF INDEPENDENCE para. 2 (U.S. 1776) ("That whenever any Form of Government becomes destructive of these ends, it is the Right of the People to alter or to abolish it, and to institute new Government, laying its foundation on such principles and organizing its powers in such form, as to them shall seem most likely to effect their Safety and Happiness."); VIRGINIA DECLARATION OF RIGHTS art. III (1776), reprinted in 5 THE FOUNDERS' CONSTITUTION 3, 3 (Philip B. Kurland \& Ralph Lerner eds., 1987) ("[W]henever any government shall be found inadequate or contrary to these purposes, a majority of the community hath an indubitable, unalienable, and indefeasible right, to reform, alter, or abolish it, in such manner as shall be judged most conducive to the publick weal.").

80. THE DECLARATION OF INDEPENDENCE para. 31 (U.S. 1776).

81. Id. para. 2 ("[W] hen a long train of abuses and usurpations, pursuing invariably the same Object evinces a design to reduce them under absolute Despotism, it is their right, it is their duty, to throw off such Government, and to provide new Guards for their future security."). 
In addition to grounding the right in natural law, the North American colonists grounded their actions in English constitutional law. ${ }^{82}$ They noted that Blackstone characterized the laws of England as including a law of redress against public oppression. ${ }^{83}$ Consistent with the structure outlined above, the colonists did not specify, nor feel that they needed to identify, an alternative ruler.

In treating resistance as a human right, Americans of the founding era were informed by state constitutionmakers who themselves favored a rhetoric of resistance and popular sovereignty. ${ }^{84}$ To this day, many U.S. state constitutions grant a right to their citizens to abolish the government. ${ }^{85}$ For example, the constitutions of New Hampshire, North Carolina, and Tennessee have the identical phrase " $t]$ he doctrine of nonresistance against arbitrary power, and oppression, is absurd, slavish, and destructive of the good and happiness of mankind." 86 This phrase seems to have originated with New Hampshire's revolutionary-era

82. See FRITZ, supra note 78, at 13 (noting that the right of revolution "reflected a well-known justification for revolution under both natural law and English constitutional doctrine").

83. Id. (explaining that at the time of the revolution, English law recognized what William Blackstone called "the law of redress against public oppression" (quoting 1 WILLIAM BLACKSTONE, supra note 77 , at ${ }^{*} 238$ ) (internal quotation marks omitted)).

84. Id. at 24-25 (describing the treatment of the right of revolution in initial state constitutions).

85. See, e.g., KY. CONST. § 4 ("All power is inherent in the people, and all free governments are founded on their authority and instituted for their peace, safety, happiness and the protection of property. For the advancement of these ends, they have at all times an inalienable and indefeasible right to alter, reform or abolish their government in such manner as they may deem proper."); PA. CONST. art I, § 2 ("All power is inherent in the people, and all free governments are founded on their authority and instituted for their peace, safety and happiness. For the advancement of these ends they have at all times an inalienable and indefeasible right to alter, reform or abolish their government in such manner as they may think proper."); TEX. CONST. art. I, § 2 (“All political power is inherent in the people, and all free governments are founded on their authority, and instituted for their benefit. The faith of the people of Texas stands pledged to the preservation of a republican form of government, and, subject to this limitation only, they have at all times the inalienable right to alter, reform or abolish their government in such manner as they may think expedient.").

86. N.H. CONST. art. X ("Government being instituted for the common benefit, protection, and security, of the whole community, and not for the private interest or emolument of any one man, family, or class of men; therefore, whenever the ends of government are perverted, and public liberty manifestly endangered, and all other means of redress are ineffectual, the people may, and of right ought to reform the old, or establish a new government. The doctrine of nonresistance against arbitrary power, and oppression, is absurd, slavish, and destructive of the good and happiness of mankind."); Declaration of Rights and Other Amendments, North Carolina Ratifying Convention art. III (Aug. 1, 1788), reprinted in 5 THE FOUNDERS' CONSTITUTION, supra note 79, at 17 ("That government ought to be instituted for the common benefit, protection and security of the people; and that the doctrine of non-resistance against arbitrary power and oppression is absurd, slavish, and destructive to the good and happiness of mankind."); TENN. CONST. art. I, § 2 ("That government being instituted for the common benefit, the doctrine of non-resistance against arbitrary power and oppression is absurd, slavish, and destructive of the good and happiness of mankind."). 
constitution. ${ }^{87}$ This in turn had been influenced by the Maryland Bill of Rights of 1776, which provided that the people could "reform the old or establish a new government" whenever public liberty was manifestly endangered and there was no other means of redress. ${ }^{88}$ A slew of other state constitutions allowed the citizens to "alter, reform or abolish" their governments without such strict preconditions. ${ }^{89}$ This is relevant to an enduring debate over whether a revolutionary government established by the people is itself subject to further revolt, should the new government fail to uphold its end of the bargain. ${ }^{90}$

The notion of justified resistance also informs the first clause of the Second Amendment. The "well regulated militia" is characterized as necessary to the security of a free state, and there is little doubt that the explicit connection between violence and freedom turns on the notion of justified resistance. ${ }^{91}$

The United States struggled in the early years of the Republic with the issue of when resistance against authority would be justified. The Whiskey Rebellion, which broke out in western Pennsylvania in 1791 over the question of grain taxes, brought the issue to the fore. ${ }^{92}$ The rebels drew on the right to resist unjust authority in justifying their actions. While the Federalists assumed that the Constitution established a sovereign government that was to be obeyed, the rebels invoked the collective sovereignty of the people to justify their extraconstitutional resistance to the tax. ${ }^{93}$

Of course, the real innovation of American constitutionalism is the creation of judicial review, which some have argued serves to domesticate the right to resist. $^{94}$ For example, Larry Kramer recently argued that judicial review itself derives from the people's unquestioned ability to resist governmental acts and

87. See N.H. CONST. artX.

88. MD. CONST. of 1776, Declaration of Rights art. IV, reprinted in 4 SOURCES AND DOCUMENTS OF UNITED STATES CONSTITUTIONS 372, 372 (William F. Swindler ed., 1975). See generally FRITZ, supra note 78, at 24 (discussing New Hampshire borrowing Maryland's language).

89. See FRITZ, supra note 78, at 24 (discussing Pennsylvania).

90. See id. at 24-25 (reviewing provisions giving Americans the right to "alter or abolish" their constitutions); $i d$. at 268 (noting arguments that the right of revolution was "annihilated" by the federal Constitution).

91. Steven J. Heyman, Natural Rights and the Second Amendment, 76 CHI.-KENT L. REV. 237, 247-49 (2000) (discussing Lockean influence on the Second Amendment).

92. See FRITZ, supra note 78 , at 166 .

93. See id. at 173-74 (noting that the proponents of the Whiskey Rebellion protests believed that the people had the "right to monitor their governments" and that, as the sovereign, the people "had the right to alter or abolish their governments").

94. See Rubin, supra note 14, at 87 (tying judicial review to resistance); see also FRITZ, supra note 78, at 23 (quoting Alexander Hamilton for the proposition that judicial review protects popular sovereignty). 
laws that are ultra vires. ${ }^{95}$ Certainly after the decision of Marbury $v$. Madison, ${ }^{96}$ the people needed not tolerate extralegal actions by their rulers, but now had an institutional solution that fell short of exercising resistance. In some sense, then, judicial review can be seen as the end of several hundred years of evolution in the idea of justified resistance against ultra vires authority. ${ }^{97}$

\section{Other Revolutionary Thought}

Unsurprisingly, those who engage in actual revolutions tend to be quite comfortable with the right to resist. The French revolutionaries placed the right to resist as one of the central pillars in the Declaration of the Rights of Man and of the Citizen, noting that resistance to oppression was a natural right, along with those of liberty, property, and security. ${ }^{98}$ Later revolutionaries in the Marxist tradition continued to argue for a right of full-fledged revolution, not simply a right to defend an established constitutional order or to restore the status quo ante when faced with an oppressive dictator. As Mao Zedong put it, "[i]t is right to rebel against reactionaries." 99

The right to resist has also been justified in international law, in particular by those seeking self-determination. ${ }^{100}$ A notable document in this regard was the 1970 Declaration on Principles of International Law concerning Friendly Relations and Co-operation among States in accordance with the Charter of the United Nations, issued by the UN General Assembly. ${ }^{101}$ This document famously condemned the "subjection of peoples to alien subjugation, domination and exploitation" as a violation of the fundamental principle of self-determination. The Declaration provides that "[i]n their actions against, and resistance to, such forcible action in pursuit of the exercise of their right to self-determination, such peoples are entitled to seek and to receive support in accordance with the purposes and principles

95. KRAMER, supra note 28 , at 92.

96. 5 U.S. (1 Cranch) 137 (1803) (establishing the doctrine of judicial review).

97. See Rubin, supra note 14 , at 88 .

98. DECLARATION OF THE RIGHTS OF MAN AND OF THE CITIZEN OF 26 AUGUST 1789 art. 2 (Fr.), translated in 2 NIJHOFF, supra note 8, at 20.

99. Stuart R. Schram, The Party in Chinese Communist Ideology, in PARTY LEADERSHIP AND REVOLUTIONARY POWER IN CHINA 170, 196 (John Wilson Lewis ed., 1970) (internal quotation marks omitted).

100. Honoré, supra note 11, at 36-37 (explaining that "given certain conditions, there is indeed a right to rebel, a right which has some claim to a recognized place in international law" and that the right can be exercised by groups seeking "independence from the society to which it at present belongs" or, in other words, "self-determination").

101. G.A. Res. 2625 (XXV), at 121, U.N. Doc. A/8082 (Oct. 24, 1970). 
of the Charter."102 Several national liberation struggles have justified violence, including terrorism, in the name of the right to resist. ${ }^{103}$

\section{Conclusion}

In short, a right to resist has existed in many different political traditions across time and space. What all these traditions have in common is the idea that the right provides for evaluation of government performance against some sort of external standard and therefore is an ultimate constraint on its behavior. When a government exercises power in the shadow of legitimate potential resistance by the people, it will presumably behave more moderately than if it is not so constrained.

Of course the institutional problems of defining and identifying the conditions for legitimate exercise of the right to resist remain significant. The coordination issues for a large public are severe, and in the absence of successful collective action by the people, government may remain able to oppress people. Many institutions of modern government may have in some sense arisen to substitute for the right of a mass public to resist authority. As described above, Edward Rubin has so argued about judicial review. ${ }^{104}$ The existence of the international human rights regime has also been rooted in the need to protect the people and has in theory if not practice substituted for the exercise of the right to resist. ${ }^{105}$ Our specific concern is the right to resist in constitutions, to which we now turn.

\section{POSITIVE THEORY:WHYDOSTATES ADOPTARIGHTTO RESIST?}

When might constitutional designers provide a right to resist in a constitution? To some extent, it is puzzling that they would ever do so, as they might

102. Id. at 124 .

103. See INT'L COUNCIL ON HUMAN RightS POLICY, TALKING ABOUT TERRORISM: RiSKS AND CHOICES FOR HUMAN RigHTS ORGANISATIONS 25-27 (2008), www.ichrp.org/files/ reports/35/129_report_en.pdf (noting that some have argued "that the right of resistance is justified in asymmetrical conflicts, where one side (usually the state) has overwhelming military superiority. Without access to comparable weapons, ... armed groups are not in a position to take on 'military targets' and are obliged to attack softer targets, including civilians").

104. See Rubin, supra note 14, at 87 (noting that in the United States judicial review serves as an alternative to revolution or resistance).

105. See Walter Kälin \& Jörg Künzli, Article $1 F(b)$ : Freedom Fighters, Terrorists, and the Notion of Serious Non-Political Crimes, 12 INT'L J. RefugeE L. 46, 51 (2000) (“[W]ithin the context of international protection afforded by human rights, entitlement to resist is superseded by an entitlement to resort to constitutional procedures before national and international authorities responsible for ensuring the safeguarding of human rights positions."). But see Kopel et al., supra note 63, at 171-73 (arguing that the human right to self-defense under international law implies a right to possess some types of arms). 
ultimately be overthrown themselves through the exercise of such a right. ${ }^{106}$ As Honoré puts it, "Sovereign states can hardly be expected as a matter of course to grant their subjects a right to secede or rebel." 107 Yet sometimes, paradoxically, they do.

In this Part, we set forth two primary explanations for why states might adopt a right to resist in their constitution. First, we suggest that states might adopt such a right as a forward-looking coordination device that precommits the nation to democratic rule. Second, and potentially more troubling, we suggest the right might also be adopted as a backward-looking ex post legitimation of leaders who obtained power through undemocratic means.

\section{A. A Forward-Looking Right: Coordination and Precommitment}

One explanation for why constitutionmakers would enshrine a right to resist in their constitution is to serve as a forward-looking precommitment device that helps to coordinate the necessary popular response in cases of illegitimately exercised or formulated government authority. To understand the notion of coordination, let us begin with Barry Weingast's simple model of democracy and the rule of law. Weingast models a situation in which there is one leader and two citizens. The leader can form a coalition with one or the other citizen to appropriate wealth from the other citizen. ${ }^{108}$ Under some circumstances, however, the ruler may desire to impose limitations on herself, perhaps to promote economic development or to secure political support. ${ }^{109}$

106. Cf. Tom Ginsburg \& Mila Versteeg, Why Do Countries Adopt Constitutional Review? 1 (July 2012) (unpublished manuscript), available at https://www.utexas.edu/law/academics /centers/clbe/wp/wp-content/uploads/centers/clbe/versteeg_why_do_countries_adopt.pdf (calling it an "important puzzle[] of political economy" that self-interested leaders would "constrain themselves by constitutional means").

107. Honoré, supra note 11 , at 42.

108. Barry R. Weingast, The Political Foundations of Democracy and the Rule of Law, 91 AM. POL. SCI. REV. 245, 247-48 (1997) (providing a simple model of democratic rule that involves a problem of pure coordination due to sovereign transgressions).

109. There is a long literature that suggests a link between constitutional constraints and economic development. See, e.g., Daron Acemoglu \& Simon Johnson, Unbundling Institutions, 113 J. POL. ECON. 949, 953 (2005) (suggesting that institutions with "greater constraints on politicians" are crucial for economic growth); Rafael La Porta et al., Judicial Checks and Balances, 112 J. POL. ECON. 445 (2004) (finding an empirical link between judicial constraints and economic freedom and property rights); Paul G. Mahoney, The Common Law and Economic Growth: Hayek Might Be Right, 30 J. LEGAL STUD. 503 (2001) (finding that the common law tradition of a free market and limited government is associated with economic growth); Douglass C. North \& Barry R. Weingast, Constitutions and Commitment: The Evolution of Institutions Governing Public Choice in Seventeenth-Century England, 49 J. ECON. HIST. 803 (1989) (demonstrating how legal limitations on rulers' arbitrary power in early capitalist Europe increased the legal security and predictability of external lenders who were protected by law from the seizure of their capital, and by reducing the 
If the leader promises not to act in a certain way, what is it that makes the promise enforceable? The ruler can theoretically violate any such promise with impunity unless the two citizens cooperate to enforce the constitutional promise. ${ }^{110}$ Enforcement requires citizens to coordinate among themselves to reach a shared understanding of what exactly constitutes a violation sufficient to necessitate popular action. If only one citizen thinks the leader has violated the promise and shows up in the street to protest, the citizen will be arrested and the leader will continue to violate the promise. If both citizens show up together, however, they can successfully resist the violation and enforce the constitution. ${ }^{111}$

How might such shared understandings come about? Sometimes they may be facilitated by a court decision that identifies a constitutional violation. ${ }^{112}$ In other cases, the media may play a role. In the recent revolutions in Egypt and elsewhere in the Arab world, Facebook, Twitter, and other social media allowed citizens to coordinate their understanding of when and where to protest. ${ }^{113}$ The right to resist might also play such a role. Providing an explicit right to resist in the constitution should, other things being equal, facilitate coordination because it reminds citizens of their collective power. If citizens know that there is a right to rebel, they can more easily invoke it to engage in collective action to constrain the rulers. ${ }^{114}$

Because the right to resist potentially coordinates citizens, it functions as a precommitment device. A ruler that lays out such a right in the constitution clearly signals her willingness to abide by the constitution. Reminding the people of their ultimate enforcement power in the constitutional order means that the leader

risks associated with lending, capital became more readily accessible, economic growth increased, and the relative positions of countries where sovereigns had limited themselves improved markedly).

110. Weingast, supra note 108, at 248 ("The structure ... induces a problem of coordination among the citizens. If all act in concert, then they can prevent transgressions. If they fail to act in concert, then the sovereign can transgress the rights of citizens and survive.").

111. See id. at 247 ("If both $A$ and $B$ challenge, then the sovereign is deposed, and any attempted transgression is rebuffed. If only one group challenges [the sovereign], then the challenge fails, and the transgression succeeds.").

112. See Tom Ginsburg \& Richard H. McAdams, Adjudicating in Anarchy: An Expressive Theory of International Dispute Resolution, 45 WM. \& MARY L. REV. 1229, 1270-71 (2004) (noting that court decisions can serve as coordination devices); David S. Law, A Theory of Judicial Power and Judicial Review, 97 GEO. L.J. 723, 770-76 (2009).

113. See Jose Antonio Vargas, Spring Awakening: How an Egyptian Revolution Began on Facebook, N.Y. TIMES, Feb. 17, 2012, http:/www.nytimes.com/2012/02/19/books/review/how-an-egyptianrevolution-began-on-facebook.html ("What bubbled up online inevitably spilled onto the streets, starting with a series of 'Silent Stands' that culminated in a massive and historic rally at Tahrir Square in downtown Cairo. [The Facebook page] 'We Are All Khaled Said' helped ignite an uprising that led to the resignation of President Hosni Mubarak and the dissolution of the ruling National Democratic Party.").

114. John M. Carey, Parchment, Equilibria, and Institutions, 33 COMP. POL. STUD. 735, 735-61 (2000). 
promises not to abuse the citizens, and we might expect better performance from rulers who take on such burdens. It is in this sense that the right to resist is a precommitment not to abuse other rights.

Constitutions have long been conceptualized as precommitment devices that solve time-inconsistency problems. ${ }^{115}$ The logic is as follows: We the people decide now (time one) that we want a government that respects our rights. But we the people also know that governments, and even popular majorities, might be tempted to violate rights at a later time (time two). For this reason, we write a constitution that places certain values outside the realm of ordinary politics. Protecting such values, however, requires some mechanism that forces governments to stick to the earlier precommitments. In Homer's Odyssey, Ulysses uses ropes to tie himself to the mast of his ship, enabling him to hear the singing of the sirens while mitigating the potential dangers to himself and to his crew should their unearthly voices render him insane. ${ }^{116}$ In the constitutional realm, the judiciary is typically regarded as the rope that binds us to our earlier precommitment. ${ }^{117}$ But ultimately, the people themselves play this function when they take to the streets to resist illegitimate authority. To the extent that the right to resist facilitates such collective action, it functions as a precommitment device.

When the right to resist serves as a precommitment device, it is fundamentally forward looking: It is written with an eye to preventing rights abuses in the future. Constitutions, in general, are regarded as forward-looking documents. Since the Enlightenment, and its faith in the possibility of rationally designing society, ${ }^{118}$ constitutions are often built on the premise that " $[t]$ he past is a foreign country"119 and that drafters can design a better world. As Enlightenment philosopher Thomas Paine famously put it, "A constitution is a thing antecedent

115. See generally Jon Elster, Majority Rule and Individual Rights, in ON HUMAN RIGHTS: THE OXFORD AMNESTY LECTURES 175, 187-89 (Stephen Shute \& Susan Hurley eds., 1993) (discussing how majority rule can infringe on individual rights owing to momentary interest and how constitutionalism acts as a restraint on majority rule); Stephen Holmes, Precommitment and the Paradox of Democracy, in CONSTITUTIONALISM AND DEMOCRACY 195, 195-96 (Jon Elster \& Rune Slagstad eds., 1988) (describing the relationship between democracy and constitutionalism in historical perspective).

116. HOMER, THE ODYSSEY OF HOMER 189-90 (Richmond Lattimore trans., Harper \& Row 1967).

117. See Daryl J. Levinson, Parchment and Politics: The Positive Puzzle of Constitutional Commitment, 124 HARV.L. REV. 657, 661 (2011) ("Judicial review is commonly portrayed as the fail-safe mechanism by which constitutional commitments become practically binding.").

118. For a brief account of the social and political context of the Enlightenment, see generally RANDALL LESAFFer, European Legal History: A CUltural and Political PERSPECTIVE 37292 (Jan Arriens trans., 2009).

119. This well-known phrase comes from L.P. HARTLEY, THE GO-BETWEEN 9 (7th prtg. 1963). 
to a government, and a government is only the creature of a constitution." 120 When precommitting to certain future goals, the past may factor into the document as something to avoid but not as something to retain or aspire to. ${ }^{121}$

This logic suggests that the right to resist is likely to be a feature of democratic regimes. Democratic regimes are most likely to engage in forward-looking, self-binding action and to designate the people at large as the ultimate enforcer of constitutional rule. Moreover, constitutionmakers may be particularly susceptible to this logic of precommitment through popular resistance during democratic transitions when they are moving away from an undemocratic past. During such transitions, the possibility of illegitimate government power is fresh in the mind of constitutional designers, and they will regard the right to resist as an appealing insurance policy to prevent backsliding into an undemocratic past. ${ }^{122}$ It is no coincidence, for example, that the state constitutions of the German Länder adopted a right to resist after World War II, ${ }^{123}$ while the right for all Germans to "resist any persons seeking to abolish this constitutional order" was later enshrined in the West German Federal Constitution. ${ }^{124}$ Similarly, a number of Eastern European countries adopted a right to resist when writing their new democratic constitutions in the early $1990 \mathrm{~s},{ }^{125}$ committing to a new democratic

120. Thomas Paine, Rights of Man, in Rights of Man, COMmOn Sense, AND Other POLITICAL WRITINGS 83, 122 (Mark Philp ed., Oxford Univ. Press 1995) (1791).

121. See ANDRÁS SAJÓ, LIMITING GOVERNMENT: AN INTRODUCTION TO CONSTITUTIONALISM 1-3 (Cent. Eur. Univ. Press 1999) (suggesting that constitutions describe the future with reference to the past, and that "[f] ear of Nazi rule" informed the German constitution, while fear of communism informed the writing of constitutions in post-communist Eastern Europe).

122. Cf. Tom Ginsburg, Locking in Democracy: Constitutions, Commitment, and International Law, 38 N.Y.U. J. INT'L L. \& POL. 707, 712 (2006) (arguing that constitutional commitments to international law "may help to 'lock in' democracy domestically" and prevent undemocratic backsliding); Andrew Moravcsik, The Origins of Human Rights Regimes: Democratic Delegation in Postwar Europe, 54 INT’L ORG. 217, 230-34, 243-44 (2000) (finding, empirically, that newly established democracies are more likely to be supporters of binding rights regimes than either established democracies or nondemocracies, and that they are so in order to lock-in democracy).

123. See Bielefeldt, supra note 27 , at 1100 ("The right to resist was formally enshrined in some of the new German Land constitutions that came into being after World War II.").

124. GRUNDGESETZ FÜR DIE BUNDESREPUBLIK DEUTSCHLAND [GRUNDGESETZ] [GG] [BASIC LAW], May 23, 1949, BGB1. II, art. 20(4) (Ger.) (amended in 2010), translated in DEUTSCHER BUNDESTAG: BASIC LAW FOR THE FEDERAL REPUBLIC OF GERMANY 27 (Christian Tomuschat et al. trans., 2010) ("All Germans shall have the right to resist any person seeking to abolish this constitutional order, if no other remedy is available.").

125. See, e.g., Ústavní zákon č. 2/1993 Sb., Ústava Ceské Republiky [The Charter of Fundamental Rights and Freedoms as Part of the Constitutional Order of the Czech Republic] Dec. 16, 1992, art. 23 (amended by Const. Act. no. 162/1998), translated in GISBERT H. FLANZ, CONSTITUTIONS OF THE COUNTRIES OF THE WORLD: THE CZECH REPUBLIC 159 (Albert P. Blaustein \& Gisbert H. Flanz eds., 1993) ("Citizens have the right to resist anybody who would do away with the democratic order of human rights and fundamental freedoms, established by this Charter, if the work of the constitutional organs or the effective use of legal means are made 
future that would avoid repetition of their repressive pasts. ${ }^{126}$ And perhaps most striking, the 2003 Rwandan Constitution includes a right to resist to prevent a repeat of its genocidal past in the future. Article 48 proclaims that every citizen "has the right to defy orders received from his/her superior authority if the orders constitute a serious and manifest violation of human rights and public freedoms." 127 Thus, our first hypothesis is that constitutionmakers adopt a right to resist to protect democratic rule, particularly during democratic transitions when the right will serve as a forward-looking precommitment device to prevent undemocratic backsliding.

\section{B. A Backward-Looking Right: Ex Post Legitimation of Dictatorial Rule}

Thus far, our analysis has focused on the right to resist as a forward-looking constitutional device. To be sure, constitutions are almost universally framed as prospective documents, designed to secure certain goals for both the present and the future. Yet there might be circumstances under which constitutionmakers desire to protect and legitimate the past rather than avoid repeating it in the future. In these instances, the right to resist is commandeered into serving a darker purpose: the ex post legitimation of otherwise illegal actions wherein undemocratic coupmakers, caudillos, or commanders have overthrown the previous constitutional order.

The idea that constitutional development may be guided more by preoccupation with the past than by planning for the future is largely foreign to contemporary constitutional theory. ${ }^{128}$ The idea fits, however, with an older constitutional theory that emerged as a conservative response to Enlightenment thought ${ }^{129}$ and was articulated in the works of eighteenth-century philosophers

impossible."); Ústava SLOVEnSKeJ RePUBLIKY [CONSTITUTION] Oct. 1, 1992, art. 32 (Slovk.), translated in Constitution of the Slovak Republic, CONST. CT. SLOVK., http:// www.concourt.sk/en/A_ustava/ustava_a.pdf (last visited Mar. 5, 2013) ("The citizens shall have the right to resist anyone who would abolish the democratic order of human rights and freedoms set in this Constitution, if the activities of constitutional authorities and the effective application of legal means are restrained.").

126. See Kim Lane Scheppele, Aspirational and Aversive Constitutionalism: The Case for Studying CrossConstitutional Influence Through Negative Models, 1 INT'L J. CONST. L. 296, 303 (2003) (noting how the Former Polish Constitutional Court Justice Lech Garlicki observed that after the fall of communism, there were "several hopes as to the functions to be fulfilled by the new constitutional instruments: to demonstrate a clear rejection of the communist past, to create legal foundations of the new democratic order, to describe and confirm the new identity of the nation").

127. CONSTITUTION DE LA RÉPUBLIQUE DU RWANDA, June 4, 2003, art. 48.

128. But see Scheppele, supra note 126.

129. See Mila Versteeg, Unpopular Constitutionalism, 88 IND. L.J. (forthcoming 2014) (describing this tradition). 
writing in the British common law tradition, most notably Edmund Burke. ${ }^{130}$ According to this theory, constitutions are the accumulated experience of the past and a reflection of a nation's history. ${ }^{131}$ To rephrase the famous words of Oliver Wendell Holmes, "the life" of constitutional law is not logic but experience. ${ }^{132}$ In continental Europe, similar ideas were propagated by Karl Friedrich von Savigny, who thought that law should reflect the Volksgeist, or the spirit of the nation. ${ }^{133}$ In this conservative conceptualization, constitutions are written to preserve the past, rather than to transform and transcend it. ${ }^{134}$

These backward-looking notions of constitutionalism were largely defeated by the more functional and rational premises of Enlightenment ideals about constitutional development. ${ }^{135}$ Constitutionmaking today is usually considered an act of rational design, of intelligent men and women coming together and shaping the world anew. ${ }^{136}$ But the fact that constitutions almost universally purport to be forward looking does not preclude history from affecting the constitutionwriting process in perhaps unexpected ways, as the example of the right to resist seems to suggest. While normative political theorists have largely ignored this aspect of modern constitutionalism, it is possible that, as a sociological matter, a right to resist can be adopted with a retrospective rather than prospective orientation. In fact, an examination of the actual cases in which the right is adopted suggests that this right does not always coincide with a liberal democratic transition. More often than not, it follows a fundamentally undemocratic event: the coup d'état.

In Portugal, for example, the Estado Novo grabbed power through a forceful though bloodless military coup in $1926 .{ }^{137}$ Over the following years, former eco-

130. See F.A. HAYEK, THE CONSTITUTION OF LiBERTY 55-56 (1960) (noting that this tradition "was made explicit mainly by a group of Scottish moral philosophers led by David Hume, Adam Smith, and Adam Ferguson, seconded by their English contemporaries Josiah Tucker, Edmund Burke, and William Paley, and drawing largely on a tradition rooted in the jurisprudence of the common law" (footnote omitted)).

131. See Edmund Burke, Reflections on the ReVolution In France 66 (L.G. Mitchell ed., Oxford Univ. Press 1993) (1790).

132. Oliver Wendell Holmes, JR., The COMMONLAW 5 (Transaction Publishers 2005) (1881).

133. See FrEDERICK CHARles VON SAVIGNY, OF THE VOCATION OF OUR AgE FOR LEGISLATION AND JURISPRUDENCE 30 (Abraham Hayward trans., Arno Press 1975) (1831).

134. Cf. Cass R. Sunstein, Social and Economic Rights? Lessons From South Africa 4 (Chi. Pub. Law \& Legal Theory Working Paper No. 12, 2001), available at http://papers.ssrn.com/paper.taf? abstract_id=269657 (distinguishing between "transformative" and "preservative" constitutions).

135. Cf. Harold J. Berman, The Historical Foundations of Law, 54 EMORY L.J. 13, 16-17 (2005) (describing how the historical tradition lead by Von Savigny became an important school of thought in the nineteenth century but diminished in the twentieth century).

136. See HAYEK, supra note 130 , at 57 .

137. See Library Of CONG., Fed. Research Div., Portugal: A Country Study 54 (Eric Solsten ed., 2d ed. 1994) ("The coup d'état was bloodless because no military units came to the aid of the government."). 
nomics professor Antonio de Oliveira de Salazar emerged as the leader of the new regime and decided to single-handedly write a new constitution ${ }^{138}$ to consolidate and implement his vision of the "New State." ${ }^{39}$ The resulting document, ratified into law in 1933, was essentially a decorative fiction enumerating and delineating myriad rights that were never actually respected in practice. ${ }^{140}$ Yet prominently positioned among the rights was the " $[t]$ he right of resistance to any order which may infringe individual guarantees," ${ }^{141}$ which is exactly how the Estado Novo had itself come into existence almost a decade before.

Or consider the case of Ghana. In the summer of 1979, Flight Lieutenant Jerry Rawlings and his Armed Forces Revolutionary Council overthrew Ghana's Supreme Military Council, which had been transitioning the country toward democratic rule and was writing a new popular constitution. ${ }^{142}$ Rawlings executed a large number of those who had been in a position of power during the previous period and gained full control over the country. ${ }^{143}$ In the course of substantially amending the constitutional document that had been drafted only months previously, Rawlings introduced the right to resist. ${ }^{144}$

Likewise, in 1945, Guatemalan dictator Jorge Ubico was forced from power through popular protests. ${ }^{145}$ The country was briefly ruled by an associate appointed by Ubico but quickly experienced another coup d'état when a joint civilian-military junta took control of the government. ${ }^{146}$ Following the coup,

138. Id. at 56 (stating that Salazar dictated the 1933 Constitution).

139. See FiliPE RibEIRO DE MENESES, SALAZAR: A POLITICAL BIOGRAPHY 105-06 (2009).

140. See id. at 106-07 ("[W] hile there were many guarantees of civil and political rights, all of these were subjected to a number of conditions that were shamelessly exploited by the executive.").

141. CONSTITUİÇAO POLÍTICA DA REPÚBLICA PORTUGUESA [C.R.P.] [CONSTITUTION] Feb. 22, 1933, art. 8(19) (Port.) (amended Dec. 21, 1936), translated in 136 BRITISH AND FOREIGN STATE PAPERS 56 (1938).

142. Library OF CONG., FED. Research DiV., GHANA: A COUNTRY STUDY 45-47 (LaVerle Berry ed., 3d ed. 1995) (noting that after the constitutional commission had submitted an "approved draft" of the new constitution, "[a]11 appeared set for a new attempt at constitutional government in July, when a group of young army officers overthrew the SMC government in June 1979").

143. Id. at 47 (observing that Rawlings executed "former heads of military governments" including "leading members of the SMC" who were in power before the coup).

144. CONSTITUTION OF THE REPUBLIC OF GHANA, Sept. 18, 1979, art. 1(3) (“All citizens of Ghana shall have the right to resist any person or persons seeking to abolish the constitutional order as established by this Constitution should no other remedy be possible.").

145. LIBRARY OF CONG., FED. RESEARCH DIV., GUATEMALA: A COUNTRY STUDY 22 (Richard F. Nyrop ed., 2d ed. 1983) ("The downfall of Ubico came about in classical fashion when the dictator escalated a conflict growing out of a student demonstration until most of the urban population turned against him.”).

146. Id. ("[Ubico] transferred power to an associate, Juan Federico Ponce Vaides, . . . but intensified popular resistance led to open fighting in October [of 1944]. Ponce was forced to resign and was replaced by a joint civil-military junta."). 
the new military regime quickly adopted a new constitution ${ }^{147}$ and enshrined a provision that declared that "[a]dequate resistance for the protection of the individual rights . . . is legitimate." 148 The army later invoked legal obligations to justify the 1982 coup. ${ }^{149}$

Hugo Chavez provides an example of a democratically elected leader who may have embraced the right to resist in hopes of absolving himself of illegal acts committed prior to his consolidation of power. In 1992, Chavez spearheaded an attempted coup against the government of Venezuela, then headed by Carlos Andres Perez. ${ }^{150}$ The plot miscarried and Chavez served time in jail for his role, although the young officer remained a hero to many Venezuelans opposed to the perceived corruption and cronyism of the Perez government. ${ }^{151}$ Following his release, Chavez rode this wave of popularity into the presidential office, despite

147. See MARIO Rosenthal, GuATEMAla: THE StORY OF AN EMERGENT LATIN-AMERICAN DEMOCRACY 216 (1962) (noting that in the first five months following the coup, "the constitution was repealed" and "a new constitution was drawn up," which was approved "on March 13[, 1945], a mere two days before the inauguration").

148. CONSTITUCión POlítica de la RePÚBliCA DE GUATEMAla [CONSTITUTION] Mar. 11, 1945, art. 50, translated in 145 BRITISH AND FOREIGN STATE PAPERS 1121 (1953). Note that Guatemala expanded the purview of this provision in 1965 following another coup. CONSTITUCIÓN DE LA REPÚBLICA DE GUATEMALA DECRETADA POR LA ASAMBLEA NACIONAL CONSTITUYENTE EN 15 SEPTIEMBRE DE 1965 [CONSTITUTION] Sept. 15, 1965, art. 77, translated in 4 AMOS J. PEASLEE \& DOROTHY PEASLEE XYDIS, CONSTITUTIONS OF NATIONS 578 (PanAmerican Union trans., rev. 3d ed. 1970) ("The rights and guarantees granted by the Constitution do not exclude others which, although not expressly indicated therein, are inherent in the human person. Laws and governmental orders or those of any other kind that regulate the exercise of rights guaranteed by the Constitution shall be null and void ipso jure if they diminish, restrict, or distort such rights.").

149. While technically differentiated from their use in ratified national constitutions, the use of right-toresist justifications within provisional constitutions and constitutional suspension decrees that follow an extralegal seizure of power can be highly informative as to the legitimation pressures faced by their authors. See, e.g., Fundamental Statute of Government, Decree Law 24-82, Apr. 27, 1982, pmbl. (Guat.) ("[T] he Army of Guatemala, in fulfillment of its obligations to the Nation, echoing the feelings of the people and seeking to safeguard the national honor, deposed the ruling regime, the outgrowth of a system completely oblivious of legality that brought the country into a state of anarchy and international isolation which with disregard of human life, of honesty in the management of public affairs, and of the rights of citizens, culminated in an election vitiated by fraud."); see also Zafar Ali Shah v. Musharraf, (2000) 52 PLD (SC) 869, 885 (Pak.) (noting that "[i]n the context of the present case the terms coup d'état and revolution are interchangeable and nothing substantial would turn on considering it from one angle or another" and citing several other cases).

150. Nikolas Kozloff, Hugo Chávez: Oil, Politics, And the Challenge to THE UNITED STATES 47 (2006) (describing how “[o]n February 4, 1992, Lieutenant Colonel Chávez . . . and 6,000 troops attacked Caracas and three other cities," attempting to overthrow the government run by Carlos Andrés Pérez).

151. See Richard GotT, Hugo ChávEZ AND the Bolivarian REVOLUTION 67 (2d ed. 2005) (noting that after the failed coup Chavez was converted "into someone perceived as the country's potential saviour"). 
significant criticisms of his previous role in attempting to subvert the democratic order. ${ }^{152}$ One of his first acts was to oversee the design of a new constitution to replace the Venezuelan constitution of 1961, and it included a brand-new rightto-resist provision: "The people of Venezuela, true to their republican tradition and their struggle for independence, peace and freedom, shall disown any regime, legislation or authority that violates democratic values, principles and guarantees or encroaches upon human rights." 153

In all these cases, it appears that the right to resist came about because constitutionmakers sought to justify their earlier actions ex post. Rulers that themselves came to power through some sort of extraconstitutional means, such as a coup or revolution, may be more likely to include a right to resist as a way of validating their own historical experience. Rather than seek a full break with the past, the right to resist may allow present day rulers to co-opt it, positioning their current leadership roles as not only legitimate but inevitable. Together, these propositions about the right to resist lead us to surmise that rights to resist will be more common for countries that recently experienced a coup.

\section{Summary}

We thus have two very different possible justifications for a right to resist in national constitutions. Democratic regimes, we surmise, will generally adopt rights to resist for forward-looking reasons. The people serve as the ultimate authority in such regimes, and the prospect of citizen resistance will help protect the regime against backsliding. The government precommits to abiding by the constitution, looking ahead to the future. In contrast, those who come to power through unconstitutional means may themselves seek to justify their actions ex post by evoking a right to resist. We characterize this as a backward-looking justification. These are two very different rationales with very different political logics.

To be sure, the distinctions between forward-looking and backward-looking adoptions of the right to resist are differences in emphasis, not in kind. A coupmaker who adopts a right to resist to justify his own seizure of power may also be trying to motivate citizens to help protect the new regime against future

152. El Antiguo Golpista Chávez Anuncia un Nuevo Proceso Constituyente en Venezuela [Former Coup Leader Chavez Announces New Constitutional Creation Process in Venezuela], EL PAÍs, Dec. 8, 1998, http://elpais.com/diario/1998/12/08/portada/913071604_850215.html.

153. CONSTITUCIÓN DE LA REPÚBLICABOLIVARIANA DE VENEZUELA [CONSTITUTION] Dec. 20, 1999, art. 350, translated in WORLD CONSTITUTIONSILLUSTRATED78 (Jefri Jay Ruchti ed., 2010). 
coups. ${ }^{154}$ In this sense, the right to resist may play an insurance function for autocrats as well as for democrats. Likewise, democratic regimes are often informed by a past they seek to avoid. They are oriented toward the future but may be more likely to adopt a right to resist if they have a particularly oppressive past.

\section{THE RIGHTTO RESIST INTHE WORLD'S CONSTITUTIONS}

Empirical analysis of why states adopt a right to resist requires data on which countries adopted the right to resist and when. To collect such data, we analyzed every national constitution written over the past 230 years, since the adoption of the U.S. Articles of Confederation in 1781 up until 2011. ${ }^{155}$ For each constitution, the text of the entire document was analyzed to determine whether the document includes the right to resist. The various general coding rules necessary to quantify written constitutions are described in greater detail in our earlier work. ${ }^{156}$

\section{A. The Global Spread of the Right to Resist}

Analysis of the data shows that the right to resist is a common feature of the world's constitutions. As can be seen from Figure 1, in the early eighteenth century, no less than 25 percent of all constitutions contained a right to overthrow the government. Since the mid-eighteenth century, we see a decline in the proportion of constitutions that contain such a right, mostly as a result of the proliferation of new countries and constitutional systems for which the right was not included. In absolute terms, however, the number of countries with such constitutional provisions has continued to grow.

For over a century, a mere 5 percent of all constitutions included the right to resist. It is only in the second part of the twentieth century that the right to resist began to spread more widely, to about 10 percent in the 1980 s and about 20

154. See, e.g., CONSTITUTION DE LA IVE RePUBliQue, Oct. 14, 1992, art. 45 (Togo), translated in CONSTITUTIONS OF THE COUNTRIES OF THE WORLD 9 (Gisbert H. Flanz ed., 2004) ("All citizens have the duty to combat any person or group of persons who would try to change by force the democratic order established by this Constitution.").

155. This data were collected as part of the Comparative Constitutions Project (CCP). See COMP. CONSTITUTIONS PROJECT, http://www.comparativeconstitutionsproject.org (last visited Mar. 6, 2013). We crosschecked the CCP coding against an independent coding of all written constitutions since 1946 by Versteeg. See generally Law \& Versteeg, supra note 2.

156. See ZACHARY ELKINS ET AL., THE ENDURANCE OF NATIONAL CONSTITUTIONS 48-51 (2009); Goderis \& Versteeg, supra note 2, at 29-35; Law \& Versteeg, supra note 2, at 1183-86 \& nn.85-98. 
percent today. In April of 2012, Hungary became the latest nation to adopt the right to resist. ${ }^{157}$

\section{FIGURE1. Percentage of Countries With the Right to Resist in Constitution}

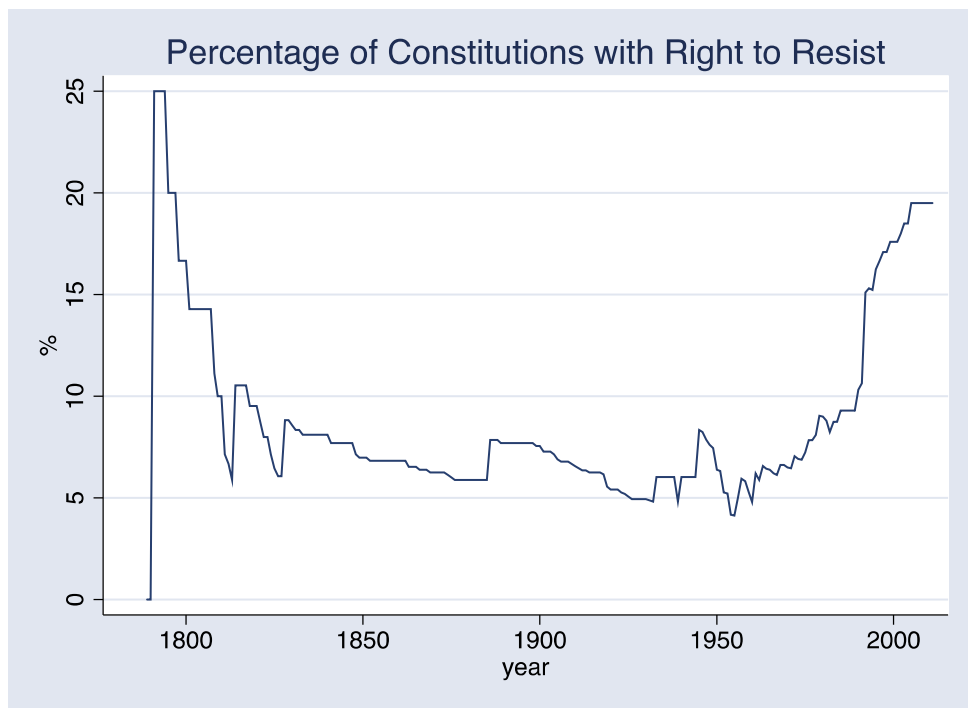

Figure 2 depicts the same information on a set of world maps at thirty-year intervals, for the years 1920, 1950, 1980, and 2010. The maps again illustrate the strong growth over time in the number of countries that include the right to resist. More important, however, the maps also show that this provision appears to be geographically clustered in Latin America, Africa, and Western Europe. By contrast, we find fewer constitutions that include this right in Asia.

157. See A Magyar KÖZTÁRSASÁg AlKotmánya [CONSTITUTION OF THE REPUBlic OF HunGARY] Apr. 25, 2011 art. C(2), translated in THE FunDAMENTAL LAW OF HuNGARY (Éva Borókainé Vajdovits ed., 2011) ("No person's activity shall be aimed at the forcible acquisition, exercise or exclusive possession of power. Every person shall be entitled and obligated to act against such attempts in a lawful way."). 
FIGURE2. Countries With the Right to Resist in Constitution in 1920, 1950, 1980 and 2010
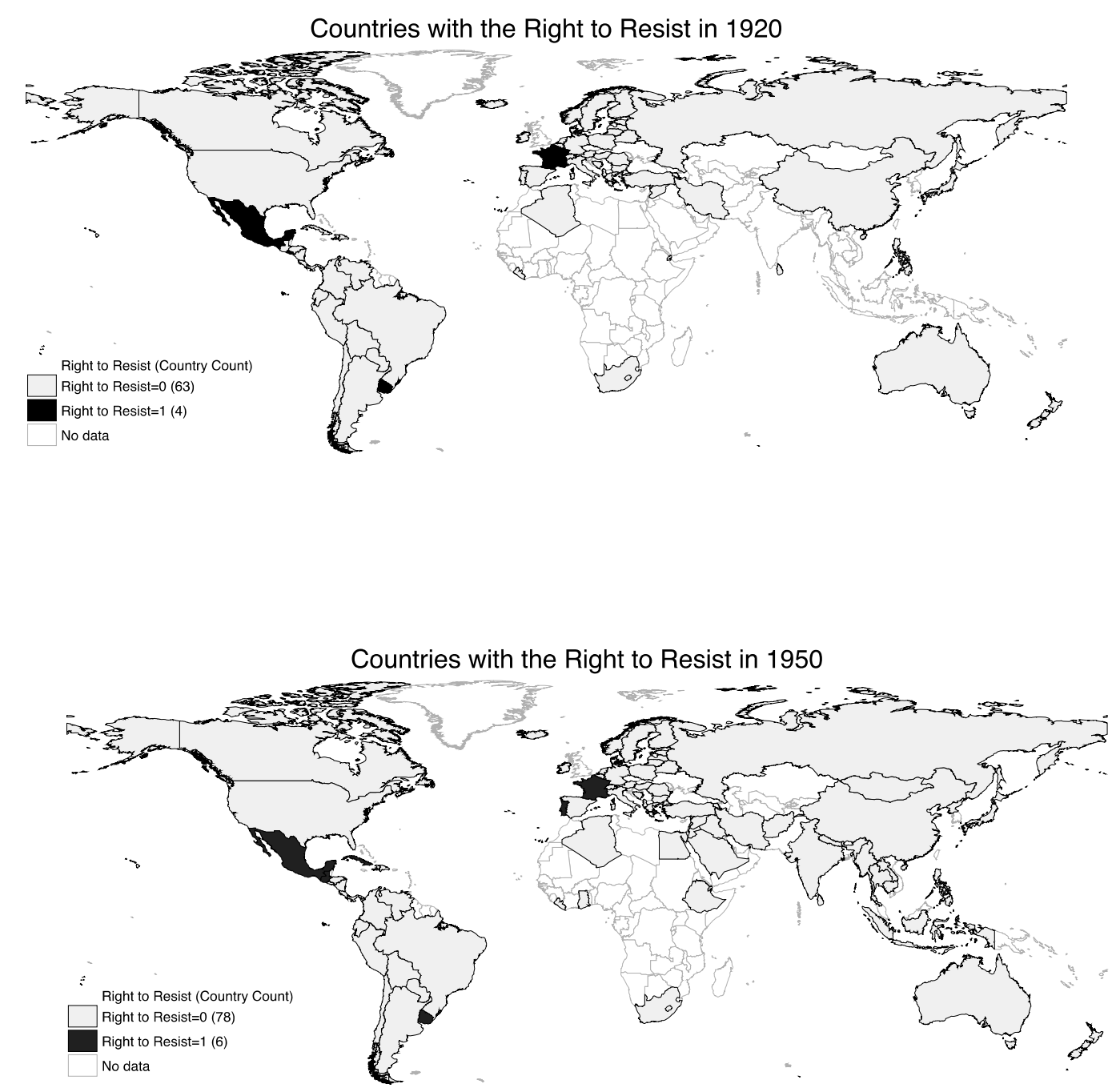

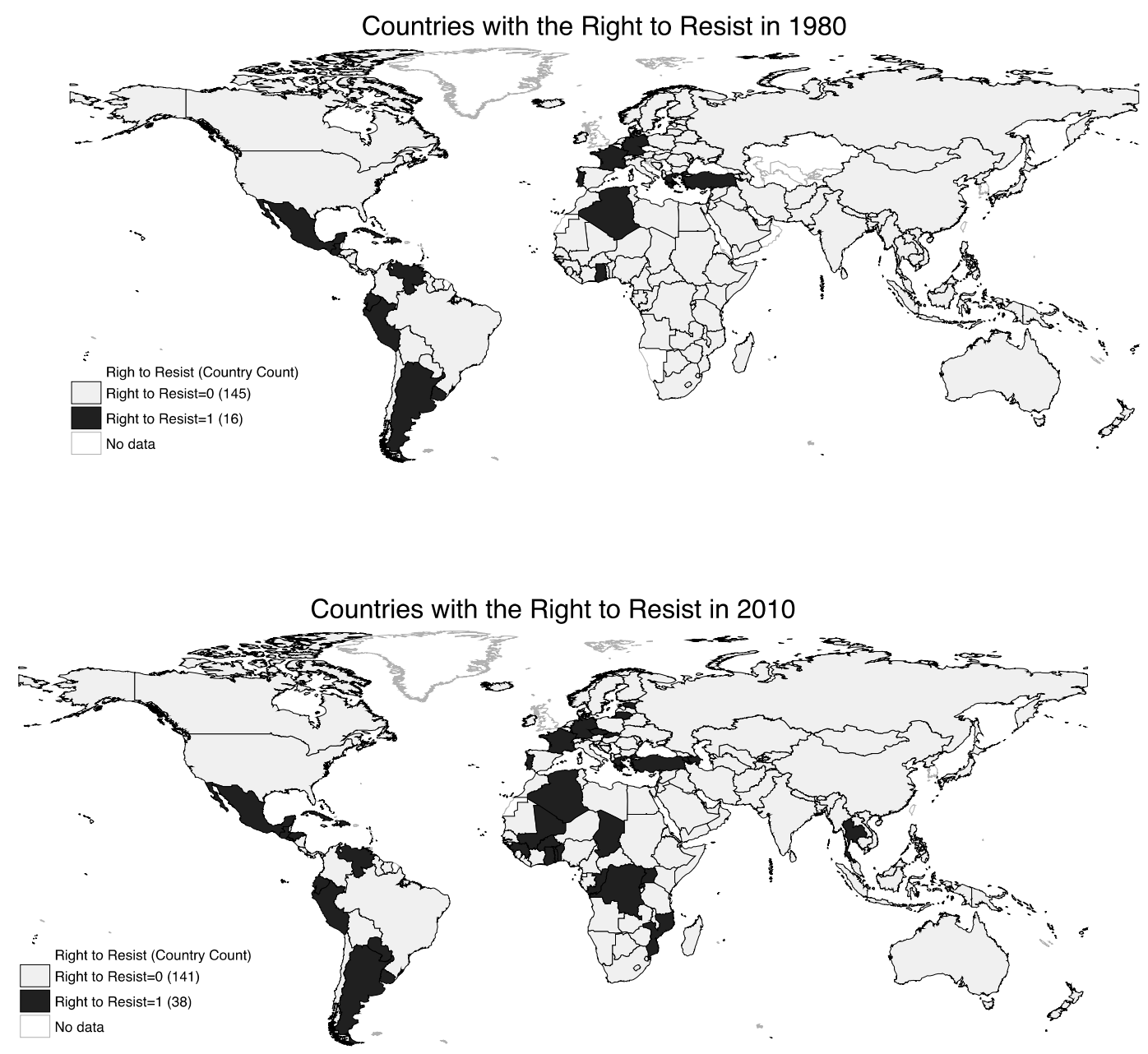

\section{B. Internal Variation Within Right-to-Resist Provisions}

In some cases we have been forced to pick and choose what to consider a right-to-resist provision for the purposes of this study. While some scholars have identified as a right to resist only those clauses in which an individual or collective 
group is allowed to defend their own rights against state encroachment, ${ }^{158}$ we have also included those provisions that allow for rebellion in the case of constitutional upheaval. For example, the Constitution of Azerbaijan states that every citizen "has the right himself to stand up to the attempt of rebellion against the state or state coup." 159 We thus adopt a broad definition of right-to-resist provisions as constitutional text enumerating a right to act against the government under certain circumstances.

Likewise, we encountered some important dimensions of variation while exploring the content of right-to-resist provisions in the world's written constitutions. One important dimension along which provisions vary is their justifying rationale. Moreover, constitutions vary in the conditions predicate to the right to resist coming into effect, in whether the provision creates a discretionary positive right or a concrete constitutional obligation, and in the scope of permitted resistance. Finally there exists variation in whether the language creates a positive right, meaning a permission to act a certain way, or a negative right, meaning only inaction is allowed-for example, ignoring an illegitimate government order. This Subpart briefly explores these internal variations within right-toresist provisions.

\section{The Rebel's Trinity: Three Justifications for the Right to Resist}

The justifying rationales behind constitutional right-to-resist provisions fall into three distinct groupings: (1) those that invoke a natural right trumping constitutional law; (2) those that create a citizen obligation to resist an overthrow of the current order; and (3) those that allow for the defense of individual rights against illegitimate actions or abuses undertaken by the state.

\section{a. Natural Law}

Right-to-resist provisions with a natural law character subordinate the existing constitution, and by extension those preceding it, to some greater law or truth. The Universal Declaration of Human Rights, for example, seems to assume a natural law right to resist, stating the following in its preamble: "Whereas it is essential, if man is not to be compelled to have recourse, as a last resort, to rebellion against tyranny and oppression, that human rights should be protected

158. See, e.g., Kopel et al., supra note 63, at 138 (listing countries with constitutional right-to-resist provisions within the context of armed and unarmed self-defense).

159. The CONSTITUTION OF THE REPUBLIC OF AZERBAIJAN, art. 54(II), available at http:// azerbaijan.az/portal/General/Constitution/doc/constitution_e.pdf. 
by the rule of law ... [t] he General Assembly Proclaims this Universal Declaration of Human Rights ...."160

It is possible that right-to-resist provisions of the natural law variety are associated in the modern era with regimes that came about through a coup. By recognizing a legal order that trumps even the constitution, these provisions can offer a Lockean justification for having overthrown the previous regime. Examples such as those of Ghana, Guatemala, and Venezuela outlined in Part II.B would fall under this rubric. Another might be Cuba's Constitution of 1940. In 1933, a group of army commanders overthrew Cuban president Gerardo Machado in an uprising known as the Sergeants' Revolt. ${ }^{161}$ Among them was a young Fulgencio Batista. ${ }^{162}$ By the time a new constitution was drafted to replace the defunct 1901 constitution following its seven-year suspension, Batista was firmly in control and the new Cuban constitution would include a right to resist based on natural rights. ${ }^{163}$

\section{b. Constitutional Defense}

In other cases, the right to resist is framed as a defense of the current constitutional order by calling on the citizenry to oppose those who aim to overthrow it. This type of right-to-resist provision forms a kind of insurance policy, in which the current government seeks to protect itself. The government assumes that the current order is the one that is legitimate and that those who aim to overthrow the current order conduct illegitimate government action. Thus, the population is empowered to act only against authorities outside the current regime, should those authorities come to power, not against the regime propagating the constitution at the time of its drafting.

160. Universal Declaration of Human Rights, G.A. Res. 217 (III) A, U.N. Doc. A/RES/217(III), at $72-72$ (Dec. 10, 1948)

161. See louis A. PÉREZ, JR., Cuba AND the United States: Ties of Singular InTimacy 162. Id. 193 (3d ed. 2003) (discussing the "Sergeants Revolt" [sic]).

163. Constitución de la República de Cuba [COnstitution] Oct. 10, 1940, art. 40, translated in WORLD CONSTITUTIONS ILLUSTRATED: CONSTITUTION OF THE REPUBLIC OF CUBA 1940, at 11 (Jefri Jay Ruchti ed., Anna I Vellvé Torras trans., 2010) ("The legal, governmental provisions or [those] of any other order which regulate the exercise of the rights which this Constitution guarantees, will be null if they diminish, restrict or corrupt . . . them. Adequate resistance for the protection of the individual rights previously guaranteed is legitimate. The action to prosecute infringements of this Title is public, without bond or formality of any kind, ... and by a simple denunciation. The enumeration of the rights guaranteed in this Title does not exclude the others that this Constitution establishes, nor others of analogous nature or that are derived from the principle of the sovereignty of the people and from the republican form of government." (first alteration in original)). 
An example is the constitution of the Federal Republic of Germany, amended in 1968 to provide that "[a]11 Germans shall have the right to resist any person seeking to abolish this constitutional order, if no other remedy is available." 164 The 1993 Constitution of the Czech Republic similarly provided that "[c]itizens have the right to resist any person who would do away with the democratic order of human rights and fundamental freedoms, established by the Charter, if the work of the constitutional organs and effective use of legal means are made impossible." 165

Another example of such a provision comes from the Argentine Constitution of 1956, which states:

This Constitution shall rule even when its observance is interrupted by acts of force against the institutional order and the democratic system. These acts shall be irreparably null. ....

Those who, as a consequence of these acts, were to assume the powers foreseen for the authorities of this Constitution or for those of the provinces, shall be punished with the same penalties and shall be civil [sic] and criminally liable for their acts....

All citizens shall have the right to oppose resistance to those committing the acts of force stated in this section. ${ }^{166}$

Ironically, though, this provision remained a part of each of the four Argentine constitutional revisions since its initial inclusion, spanning a tumultuous period of coups and rebellions over the latter half of the twentieth century. The constitutional text clearly did not prevent new coupmakers from replacing the old ones.

\section{c. Self-Defense}

In a third set of cases, the justification for inclusion of the right to resist is one of self-defense. This justification is similar to natural law in that it establishes

164. See GRUNDGESETZ FÜR DIE BundeSREPUblik Deutschland [GRUNDGESETZ] [GG] [BASIC LAW] May 23, 1949, BGB1. II, art. 20(4) (Ger.) (amended in 2010), translated in DEUTSCHER BUNDESTAG: BASIC LAW FOR THE FEDERAL REPUBLIC OF GERMANY 27 (Christian Tomuschat et al. trans., 2010).

165. Ústavní zákon č. 2/1993 Sb., Ústava České Republiky [The Charter of Fundamental Rights and Freedoms as Part of the Constitutional Order of the Czech Republic] Dec. 16, 1992, art. 23 (amended by Const. Act. no. 162/1998), translated in GISBERT H. FLANZ, CONSTITUTIONS OF THE COUNTRIES OF THE WORLD: THE CZECH REPUBLIC 159 (Albert P. Blaustein \& Gisbert H. Flanz eds., 1993).

166. Art. 36, CONSTITUCIÓN NACIONAL [CONST. NAC.] (Arg.), translated in Constitution of the Argentine Nation, SENADO DE LA NACIÓN ARGENTINA, http:/www.senado.gov.ar/web/ interes/constitucion/english.php (last visited Apr. 17, 2013). 
the right to act against the current constitutional order under certain circumstances. Whereas natural law provisions, however, allow for people to rise in rebellion against the system itself, overthrowing it if necessary should it become tyrannical or illegitimate, self-defense merely allows for people to oppose actions undertaken by government agents in violation of existing law. Often these provisions will diverge from natural law in terms of scope, empowering only individual action against individual agents rather than collective action against the state itself. One example of such a right can be found in one of the world's oldest rights documents, the 1791 French Declaration of the Rights of Man, which states that "[e]very act exercised against a man to which the cases in the law do not apply, and in which its forms are not observed, is arbitrary and tyrannical. Respect for the law forbids him to submit to such acts; and if attempts are made to execute them by violence, he has a right to repel force by force."167

Another example can be found in E1 Salvador's 1983 Constitution, which curtails its "right ... to insurrection" in cases of "serious" government violations of constitutionally established rights in the following fashion: "The exercise of this right shall not produce the abrogation nor the reform of this Constitution, and shall be limited to the removal insofar as necessary of transgressing officials, replacing them in a transitory manner until they are substituted in the form established by this Constitution." 168

\section{d. Hybrid Justifications}

Of course, there are significant overlaps among the three justifications, and many countries will include more than one within a single provision ${ }^{169}$ or constitution. ${ }^{170}$ This can, at times, invite confusion. For example, after Manuel Zelaya

167. 1791 CONST. art. 12 (Fr.), translated in 4 THE POLITICAL STATE OF EUROPE, FOR THE YEAR MDCCXCIII 176 (1793). A more modern example can be found in the Portuguese Constitution of 1976. CONSTITUİÇAO POLÍTICA DA REPÚBLICA PORTUGUESA [CONSTITUTION] Apr. 25, 1976, art. 21 (Port.), translated in OFFICE OF THE SEC'Y OF STATE FOR MASS COMMC'N, CONSTITUTION OF THE PORTUGUESE REPUBLIC 24 (1977 ("Everyone shall have the right to resist any order that infringes his rights, freedoms or safeguards and to repel by force any form of aggression when recourse to public authority is impossible.").

168. CONSTITUCIÓN DE LA REPÚBLICA DE EL SALVADOR [CONSTITUTION] Dec. 15, 1983, art. 87 (amended July 10, 1996), translated in CONSTITUTIONS OF THE COUNTRIES OF THE WORLD: REPUBLIC OF El SALVADOR 18 (Gisbert H. Flanz ed., Reka Koerner trans., 1998).

169. See id. (justifying both constitutional defense, in addition to self-defense for government violations of its own laws).

170. Venezuela, for example, establishes a right to Constitutional Defense in Article 333, alongside the aforementioned article 350. Compare CONSTITUCIÓN DE LA REPÚBLICA BOLIVARIANA DE VENEZUELA, Dec. 20, 1999, art. 333, translated in WORLD CONSTITUTIONS ILLUSTRATED: 
was removed as president of Honduras in 2009, both the exiled president and the new regime invoked, as a legal justification for their right to rule, Article 3 of the 1982 Constitution, which proclaims:

No one owes allegiance to a usurping government nor to those who assume office or public service by force of arms or by using means or procedures which violate or ignore the provisions established by this Constitution and other laws. The acts adopted by such authorities are null. The people have the right to resort to insurrection in defense of the constitutional order. ${ }^{171}$

In 2009, the exiled Zelaya invoked Article 3 using the rationale of constitutional defense, arguing that the constitutional provision required that the new regime be declared illegitimate and that he be restored. ${ }^{172}$ For their part, congressional allies of the new government argued that Article 3 should actually be interpreted as a natural law-type provision justifying the removal of Zelaya as a legitimate "insurrection" in light of Zelaya's seeking to subvert the constitutional order while president. ${ }^{173}$

VENEZUELA (Jefri Jay Ruchti ed., Ministry of Commc'n \& Info. of the Bol. Republic of Venez. trans., 2010), with id. art. 350.

171. CONSTITUCIÓN POLÍTICA DE LA REPÚBLICA DE HONDURAS, Jan. 11, 1982, art. 3, translated in CONSTITUTION OF THE REPUBLIC OF HONDURAS 1982, at 1-2 (Gen. Secretariat, Org. of Am. States ed., 1982).

172. See Zelaya Llama a la Insurreción en Honduras [Zelaya Calls for Insurrection in Honduras], EL PAís, July 15, 2009, http://internacional.elpais.com/internacional/2009/07/15/actualidad/1247608802 850215.html ("La insurrección es un derecho del pueblo que está consignado en el artículo 3 de la Constitución de Honduras, y los hondureños deben hacer valer sus derechos constitucionales." ["Insurrection is a right of the people enshrined in article 3 of the Constitution of Honduras-the people should make their rights count."] (quoting Manuel Zelaya) (internal quotation marks omitted)).

173. See Decreto de Destitución de Zelaya/Comunicado Poder Judicial Explicando Irregularidades [Official Decree of Dismisal for Zelaya/Judicial Authority Explains Irregularities], LA GACETA, July 1, 2009, available at http://asjhonduras.com/cms/docs/golpe/2009-08-10-DecretoCongreso.pdf ("Artículo 1.-El Congreso Nacional en aplicación de los artículos 1, 2, 3, 4, 5, 40 numeral 4), 205 numeral 20) y 218 numeral 3), 242, 321, 322 y 323 de la Constitución de la República, acuerda: 1) Improbar la conducta del Presidente de la República, ciudadano José Manuel Zelaya Rosales, por las reiteradas violaciones a la Constitución de la República y las leyes y la inobservancia de las resoluciones y sentencias de los órganos jurisdiccionales. 2) Separar al ciudadano José Manuel Zelaya Rosales, del cargo del Presidente Constitucional de la República de Honduras." ["Article 1: The National congress in following with articles 1, 2, 3, 4, 5, 40, 205/20, and 218/3, 242, 321, 322, and 323 of the Constitution of the Republic decrees that: 1) Official misconduct has been sanctioned upon the President of the Republic, citizen José Manuel Zelaya Rosales, for the abovementioned violations of the Constitution of the Republic and the laws and observances of its resolutions, sentences and authorities. B) Citizen José Manuel Zelaya Rosales has been removed from the position of constitutionally appointed president of Honduras."]). It may also be worth mentioning that while Zelaya himself seemingly placed considerable stock in Article 3's right to insurrection when calling upon the population to rise on his behalf, the Micheletti government did not seem to give this much credence. When the new government declared a state of emergency and temporarily suspended several constitutional rights following Zelaya's clandestine return to the country, Article 3 was not among them. See Elisabeth 


\section{Other Dimensions of Variation: Conditions Predicate, Right Versus Duty, and Scope}

In addition to varying in their justifying rationale, constitutional right-toresist provisions also vary in the conditions predicate to the right coming into effect, in whether the provision creates a right or an obligation to resistance, and in the scope and extent of the resistance that is permitted. The remainder of this Part discusses each of these in turn.

In most cases, right-to-resist provisions will identify a condition predicate in which the citizenry is entitled or obligated to act against the system established in the rest of the constitution. Sometimes rights to resist are quite general, predicated on nothing greater than the essential humanity of the people. These justifications are particularly common in rights justified by an appeal to natural law. An example of this is the 1965 Constitution of Guatemala, Article 77 of which states:

The rights and guarantees granted by the Constitution do not exclude others, which, although not expressly indicated therein, are inherent in the human person.

Laws and governmental orders or those of any other kind that regulate the exercise of rights guaranteed by the Constitution shall be null and void ipso jure if they diminish, restrict, or distort such rights. ${ }^{174}$

Other constitutions specify that the exercise of the right to resist is contingent upon a certain type of national crisis emerging. In the case of constitutional defense provisions, these crises often involve some attempt to overthrow the regime or the constitution, or an invasion of the state from abroad. For example, Article 66 of the 1990 Constitution of Benin states:

In the case of a coup d'état, of [sic] a putsch, of aggression by mercenaries or of any coup of force whatever, any member of a constitutional organ has the right and the duty to make use of [faire appel] all means to reestablish the constitutional legitimacy[,] including the recourse to existing military cooperation or defense agreements.

Malkin \& Ginger Thompson, Honduras Shuts Down 2 Media Outlets, Then Relents, N.Y. TIMES, Sept. 29, 2009, at A10; Pablo Ordaz, Micheletti Ordena el Cierre de los Medios de Comunicación Afines a Zelaya [Micheletti Orders the Closing of Media Channels Friendly to Zelaya], EL PAís, Sept. 28, 2009, http://internacional.elpais.com/internacional/2009/09/28/actualidad/1254088802_850215.html.

174. CONSTitución de la REPÚblica de Guatemala DECRETADA POR LA ASAMblea NACIONAL CONSTITUYENTE EN 15 SEPTIEMBRE DE 1965, art. 77, translated in 4 AMOS J. PEASlEE \& DOROTHY PEASLEE XYDIS, CONSTITUTIONS OF NATIONS 578 (PanAmerican Union trans., rev. 3d ed. 1970). 
In these circumstances, for all Beninese, to disobey and to organize to defeat the illegitimate authority constitutes the most sacred of rights and the most imperative of duties. ${ }^{175}$

But in some cases the national crisis could also be government tyranny or abuse, as is the case for the $1983 \mathrm{El}$ Salvador Constitution. Article 88 states that " $\mathrm{t}] \mathrm{he}$ principle that a President cannot succeed himself [alternabilidad] is indispensable for the maintenance of the established form of government and political system. Violation of this norm makes insurrection an obligation." 176

Constitutions also vary in the extent to which resistance is considered a right or an obligation. Each constitution will attempt to define whether resistance is an option, the exercise of which depends on the citizens' willingness and preferences, or a duty, wherein the people are required to act under certain conditions. Constitutional provisions run the spectrum from the aforementioned "most sacred of rights and the most imperative of duties"177 to that of a right to assemble peacefully. ${ }^{178}$

A final dimension along which constitutions vary is the scope of what is permissible under the right. More conservative approaches to the right might allow for a citizen only to disobey or resist an order-essentially a negative right. ${ }^{179}$ Alternately, they may allow for resistance only as long as the actions constituting that resistance would not themselves be illegal otherwise- a positive

175. CONSTITUTION DE LA RÉPUBLIQUE DU BENIN, Dec. 11, 1990, art. 66, translated in WORLD CONSTITUTIONSILLUSTRATED: BENIN14 (Jefri Jay Ruchti ed. \& trans., 2011) (alterations in original).

176. CONSTITUCIÓN DE LA REPÚBLICA DE El SALVADOR, Dec. 15, 1983, art. 87 (amended July 10, 1996), translated in CONSTITUTIONS OF THE COUNTRIES OF THE WORLD: REPUBLIC OF EL SALVADOR 18 (Gisbert H. Flanz ed., Reka Koerner trans., 1998).

177. CONSTITUTION DE LA RÉPUBLIQUE DU BENIN, Dec. 11, 1990, art. 66, translated in WORLD CONSTITUTIONS ILLUSTRATED: BENIN 14 (Jefri Jay Ruchti ed. \& trans., 2011); CONSTITUTION DE LA IVE REPUBLIQUE, Oct. 14, 1992, art. 150 (Togo) (amended to Feb. 7, 2007), translated in WORLD CONSTITUTIONS ILLUSTRATED: TOGO 33 (Jefri Jay Ruchti ed. \& trans., 2011).

178. BUREAU OF COMM. \& THE SECRETARIAT OF THE HOUSE OF REPRESENTATIVES, RATTHA THAMMANUN HAENG RATCHA ANACHAK THAi [CONSTITUTION] Aug. 24, 2007, sec. 63, translated in CONSTITUTION OF THE KINGDOM OF THAILAND 25 (2007), available at http://www.senate.go.th/th_senate/English/constitution2007.pdf.

179. CONSTITUIÇÃO DA REPÚBLICA DEMOCRÁTICA DE TIMOR-LESTE [CONSTITUTION] Mar. 22, 2002, sec. 28, translated in INT'L COMM. OF THE RED CROSS, CONSTITUTION OF THE DEMOCRATIC REPUBLIC OF EAST TIMOR, available at http://www.icrc.org/IHL-NAT.NSF/ 162d151af444ded44125673e00508141/127ced8944679aa5c12570910031f468/\$FILE/Constituti on\%20Timor\%20-\%20EN.pdf ("Every citizen has the right to disobey and to resist illegal orders or orders that affect their fundamental rights, freedoms and guarantees."). 
right albeit a limited one. ${ }^{180}$ At the other extreme would be those constitutions that explicitly allow for the use of force or armed insurrection. ${ }^{181}$

These dimensions of variation are broad conceptualizations, not watertight classifications. Not all right-to-resist provisions can be neatly classified along each of those dimensions. In addition, the total number of right-to-resist provisions in the world's constitutions is not large enough to analyze internal variation using statistical methods. The empirical analysis that follows focuses on the question of why a right-to-resist provision is adopted, and it ignores the intricacies of the drafting style. At the same time, Appendix I lists the full text of all historical and contemporary right-to-resist provisions that we encountered in the world's written constitutions.

\section{WHAT PREDICTS THEADOPTION OFTHE RIGHTTO RESIST?}

Over the course of the past 200 years, we see a growing number of states that constitutionally mandate the people to overthrow their government in the case of illegitimate government actions. Why do countries adopt a right to resist in their constitutions? To answer this question we turn to regression analysis. Regression analysis enables us to test whether different variables predict the adoption of this right while controlling for the presence of other variables. ${ }^{182}$ Of course, causal questions on the determinants of any constitutional right are notoriously complex and difficult to resolve using common statistical techniques and sources of data. ${ }^{183}$ To know that a particular variable predicts whether a country is more likely to adopt a right to resist does not necessarily tell us whether the variable in question actually influences adoption or merely correlates with it. Nevertheless, even correlations can shed light on the plausibility of certain hypotheses

180. HAYASTANIHANRAPETUTYYAN SAHMANADRUT'YUN [CONSTITUTION]July 5, 1995, art. 18b (amended Nov. 17, 2005) (Arm.), translated in CONSTITUTION OFTHE REPUBLIC OF ARMENIA ("Everyone shall have a right to protect his/her rights and freedoms by any means not prohibited by the law.").

181. CONSTITUCIÓN POLÍTICA DE LA REPÚBLICA DE HONDURAS, Jan. 11, 1982, art. 3, translated in CONSTITUTION OF THE REPUBLIC OF HONDURAS 1982, at 1-2 (Gen. Secretariat, Org. of Am. States ed., 1982) ("No one owes allegiance to a usurping government nor to those who assume office or public service by force of arms or by using means or procedures which violate or ignore the provisions established by this Constitution and other laws. The acts adopted by such authorities are null. The people have the right to resort to insurrection in defense of the constitutional order.").

182. See Lee Epstein \& Gary King, The Rules of Inference, 69 U. CHI. L. REV. 1, 77, 79 (2002) (stressing the need for researchers to evaluate and reject alternative explanations for their findings by employing "control variables" that account for those alternative explanations).

183. See Anne Meuwese \& Mila Versteeg, Quantitative Methods for Comparative Constitutional Law, in PRACTICE AND THEORY IN COMPARATIVE LAW 230 (Maurice Adams \& Jacco Bomhoff eds., 2012) (discussing the difficulty of distinguishing correlation from causation). 
and inform subsequent interpretations of why countries adopt right-to-resist provisions.

\section{A. The Actions of Democratic Regimes and Coupmakers}

In Part III, we developed two main hypotheses for why constitutionmakers would allow their citizens to rise up against illegitimate government power by adopting a right to resist. First, we hypothesized that the right would be associated with democratic regimes but that constitutionmakers might be particularly likely to adopt such a right during democratic transitions, and that in these cases the right serves as a precommitment device that might coordinate citizens to enforce the constitution against illegitimate government rule. Second, and in contrast with the first hypothesis, we surmised that constitutionmakers might adopt a right to resist after a fundamentally undemocratic coup, when coupmakers want to justify and legitimate their actions ex post.

To test these hypotheses, we estimate a simple regression model to explain when countries adopt the right to resist in some form. ${ }^{184}$ In this model, the dependent variable takes the value of zero prior to the year any given country adopts the right to resist, the value one in the year the country adopts a right to resist, and is missing after adoption. ${ }^{185}$ The model includes the following predictor variables to test our main hypotheses: (1) a variable that captures whether any

184. To be specific, we implemented a linear probability model, which is an ordinary least squares model for a binary dependent variable. See JEFFREY M. WOOLDRIGE, INTRODUCTORY ECONOMETRICS 246 (2002) (describing the basic assumptions underlying the linear probability model). The fact that we are analyzing time-series cross-sectional data called for a number of methodological refinements. In particular, the model is estimated with robust standard errors that are both corrected for problems of heteroscedasticity that are common to panel data and clustered at the state level to allow for serial correlation over time. Because the linear probability model does not account for the binary nature of the dependent variable, we also estimated all specifications discussed below using a probit model. When doing so, the results are in all cases almost identical to those from the linear probability model. Unlike in the probit model, however, the coefficients from the linear probability model lend themselves to easy interpretation without further calculation. The probit model with fixed effects moreover runs into the so-called incidental parameters problem. The probit results are available from the authors upon request. See Ginsburg \& Versteeg, supra note 106, at 20-43 (discussing the advantages and disadvantages of a linear probability model and probit model in the context of judicial review adoption). For these reasons, we base our discussion below on the findings from the linear probability model.

185. With this structure of the dependent variable, our model is an onset model aimed at explaining the act of adoption, rather than explaining whether countries retain the right to resist after adoption. See Goderis \& Versteeg, supra note 2, at 15 (using an onset model to explain the adoption of 108 constitutional rights provisions); Ginsburg \& Versteeg, supra note 106, at $20 \mathrm{n} .15$ (using an onset model to explain judicial review adoption). 
given country experienced a democratic transition within the past four years, ${ }^{186}$ (2) a country's level of democracy, as commonly measured in the quantitative political science literature, ${ }^{187}$ and (3) a variable that captures whether any given country experienced a coup within the past five years. ${ }^{188}$

We also include a number of predictor variables to control for other possibly competing explanations for the right to resist: (4) a country's level of economic development as measured by its energy consumption per capita, to control for the possibility that developed countries are simply more likely to adopt constitutional rights, including the right to resist; ${ }^{189}(5)$ the general political instability of the

186. Our democratic transition variable comes from the Polity IV data set, which is widely used by political scientists. The variable takes the value three in case of a "major democratic transition," the value two in case of a "minor democratic transition," and the value one in case of a "positive regime change." The variable also coded negative regime changes, but we recoded these as zero. See Monty G. Marshall \& KeIth Jaggers, Polity IV Project: Political Regime CHARACTERISTICS AND TRANSITIONS, 1800-2006, at 35-36 (2011), available at http:// www.systemicpeace.org/inscr/p4manualv2010.pdf. The four-year cutoff is motivated by the idea that constitutionmaking takes some time, and a newly democratic regime may take up to one electoral cycle to write a new constitution. We also experimented with alternative thresholds and found that the democratic transitions variable is a positive and statistically significant predictor of the right to resist in the year the transition took place as well as up to eight years afterwards, thus suggesting that our results are not dependent on selecting a four-year threshold.

187. Our measure of a country's level of democracy is the polity 2 variable from the Polity IV data set, which is also widely used by political scientists. This variable ranges from +10 (strongly democratic) to -10 (strongly autocratic). See id. at 15-16.

188. The coup d'état data comes from Arthur S. Banks \& Kenneth A. Wilson, Cross-National TimeSeries Data Archive, DATABANKS INT'L, http://www.databanksinternational.com/71.html (last visited Apr. 18, 2013). The original variable captures the number of coups d'état in each year since 1815. We recode this variable such that it takes the value of one in the year a coup takes place, as well as in the five years thereafter, and takes the value zero in all other years. The five-year cutoff is motivated by the idea that constitutionmaking takes some time, as coupmakers will only write a new constitution after they have control over the political situation, and want to further consolidate their rule. Since the average constitutionmaking process takes less than two years complete, we suspect that the five-year cutoff will capture most constitutionmaking activity that follows coups. See Tom Ginsburg et al., Does the Process of Constitution-Making Matter?, 5 ANN. REV. L. \&SOC. SCI. 201, 209 (2009) (documenting that "[o]n average, constitution-making took 16 months" in 148 surveyed cases "with a standard deviation of 22 months"). At the same time, it took about eight years for Salazar to be in the position to promulgate the 1933 Portuguese constitution, and we may miss some cases as a result of this decision. To explore the extent to which our findings are dependent on selecting the five-year threshold, we also experimented with other thresholds, and found that the coup effect is also statistically significant for all thresholds from two to ten years. In fact, the effect becomes larger and more significant for the seven-, eight-, and nine-year thresholds.

189. Empirical studies have repeatedly found that wealthy countries tend to possess superior human rights practices. See, e.g., Gerald J. Blasi \& David Louis Cingranelli, Do Constitutions and Institutions Help Protect Human Rights?, in 4 HUMAN RigHTS AND DEVELOPING COUNTRIES 223, 225-26 (Stuart S. Nagel \& David Louis Cingranelli eds., 1996). Because data on GDP per capita is only available from the 1950s onwards, we use a measure on energy consumption in lieu of GDP per capita. The data was created by J. David Singer et al., Capability Distribution, Uncertainty, and Major Power War, 1820-1965, in PEACE, WAR, AND NUMBERS 19 (Bruce M. 
country as measured by the total number of coups in a country's history, to control for the possibility that it is simply societal instability that leads countries to adopt a right to resist; ${ }^{190}(6)$ the total proportion of the world's constitutions that included a right to resist in the previous year, to control for global constitutional trends and the possibility that countries are simply emulating one another; ${ }^{191}$ and (7) the proportion of constitutions in the region that include a right to resist, to control for similar trends of a regional character. We moreover include (8) a set of binary variables for each country, also known as fixed-effects, which serve as generic controls for all country characteristics that do not change over time. These fixed-effects capture things like stable cultural attitudes and other unique national features. For example, fixed-effects would control for all those things that might make certain Asian countries less prone to constitutionally mandate rebellion than African and Latin American countries. We finally include (9) a set of time trends to control for the possibility that the probability of adopting a right to resist simply increases with time. ${ }^{192}$

Table 1 provides a summary of the results of this regression model. Variables marked with a single asterisk $\left(^{*}\right)$ are statistically significant predictors of constitutional underperformance at the $\mathrm{p}=0.10$ level, while those marked with a double asterisk $\left(^{* *}\right)$ are statistically significant at the $\mathrm{p}=0.05$ level, and those marked with a triple asterisk $\left.{ }^{* * *}\right)$ satisfy the most stringent $\mathrm{p}=0.01$ level. For the more technical reader, the full outputs of the results, such as the coefficients and standard errors, are reported in Appendix II.

Russett ed., 1972). We use the measure "energy"; it is computed using information about three broad categories of sources: petroleum, electricity, and natural gas, which is converted into one thousand metric coal-ton equivalents per capita for each country running from 1816 to 2007.

190. This measure is simply the cumulative number of coups that occurred in a country. The coup data were again taken from Banks \& Wilson, supra note 188.

191. See Law \& Versteeg, supra note 2, at 1163-64 (characterizing constitutions as remarkably standardized documents). Our construction of the regional trends variable follows the empirical literature in policy diffusion. See, e.g., Goderis \& Versteeg, supra note 2, at 23 (controlling for global trends in the "world polity").

192. Specifically, we added a linear time trend, the squared version of this time trend, and the cubed version of this time trend. See David B. Carter \& Curtis S. Signorino, Back to the Future: Modeling Time Dependence in Binary Data, 18 POL. ANALYSIS 271 (2010) (describing how this approach deals with time dependence in models with a binary dependent variables). 


\section{TABLE1. Summary of Empirical Results}

\begin{tabular}{|c|c|}
\hline Variable & Effect \\
\hline Democratic Transition & Positive \\
\hline Coup in Last Five Years & Positive \\
\hline Energy Consumption per Capita & Insignificant \\
\hline Global Adoption in Previous Year & Negative $^{* *}$ \\
\hline Regional Adoption in Previous Year & Insignificant \\
\hline Number of Coups in Nation's History & Positive $^{* *}$ \\
\hline Democracy & Positive $^{* *}$ \\
\hline
\end{tabular}

Our findings are somewhat puzzling at first: Countries are more likely to enshrine a right to resist in their constitutions both after coups and during democratic transitions. ${ }^{193}$ This finding is consistent with the idea that newly democratic countries might adopt these rights in hope of preventing undemocratic backsliding. More generally, we also find that a country's level of democracy is a statistically significant predictor of the adoption of the right to resist. All other things being equal, more democratic countries are more likely to enshrine such a right, which is consistent with the traditional conceptualization of the right as a forward-looking precommitment device serving as an enforcer of democratic rule. ${ }^{194}$ Yet even when controlling for actions of (newly) democratic nations, we also find that the right is associated with the actions of coupmakers and adopted in the aftermath of a coup d'état. ${ }^{195}$ Since coups and democratic transitions are events that are largely mutually exclusive, it seems plausible that there is some nonlinearity in the data: Some countries are attracted to the forward-looking version of the right to resist during or after a democratic transition, while others are attracted to the backward-looking version after a coup d'état. We explore this issue in some detail below.

Some of our control variables also turn out to be statistically significant predictors of right-to-resist adoption. In particular, our measure of general political instability, as measured by the number of coups d'état in a country's history, is also a statistically significant predictor of the right to resist. ${ }^{196}$ All other things being

193. In fact, during such a democratic transition, the probability of adopting the right to resist increases by 1.54 percentage points. This effect is statistically significant at the $\mathrm{p}=0.01$ confidence level.

194. In fact, a one-point increase in the twenty-point democracy scale increases the probability of adopting a right to resist by 0.006 percentage points. This means that if a hypothetical country would move from being fully autocratic to fully democratic, the probability of adoption would increase by 0.12 percentage points.

195. In fact, in each of the five years after a coup, the probability of adopting the right to resist increases by 0.86 percentage points. This effect is statistically significant at the $\mathrm{p}=0.05$ confidence level.

196. In fact, for every coup a nation has ever experienced, the probability of adopting the right to resist increases by 0.13 percentage points in each year. This effect is statistically significant at the $p=0.05$ confidence level. 
equal, unstable political systems are more likely to adopt this right. This finding is perhaps unsurprising, as political instability is likely to trigger both of our core hypotheses: Past instability makes newly democratic regimes more likely to want to prevent undemocratic backsliding, and it probably also makes coupmakers more likely to want to justify their actions. It is also possible, however, that causality runs the other way, and that constitutional systems that include a right to resist experience more instability.

We do not find any evidence of positive global or regional trends, or of the idea that countries would be influenced by the actions of others. The variable that captures previous adoption by other countries in the same region is not a statistically significant predictor of the right to resist, while the variable that captures previous adoption by all other countries in the world is actually negative, suggesting that the more countries adopt the right, the less likely others are to follow. Whatever the myriad factors that incentivize constitutionmakers to adopt a particular right, they do not include simply following the pack and copying global trends. Finally, we also find no relationship between economic development and right-to-resist adoption.

\section{B. How and Why Is Latin America Different?}

We next explore the implication that some countries may be more attracted to the right to resist during democratic transitions, while others adopt it after a coup. One potential explanation, highlighted by the figures presented in the previous Part, is that there are important regional differences in propensities to adopt the right to resist. ${ }^{197}$ As Figure 2 illustrates, some regions refrained from adopting the right altogether, while in others it emerged as early as the nineteenth century. ${ }^{198}$ To explore whether there are regional differences in the way in which the right is adopted, we divide our data into different regional subgroups to test whether the same model described above produces different results for different regions. ${ }^{199}$

Our main finding from this exercise concerns Latin America. Latin American nations are much more likely to adopt the right to resist after a coup

197. We also explored other possible explanations, in particular whether internal variation in how the right to resist is written may explain the different circumstances under which it is adopted, but we did not find any evidence to support this hypothesis. The number of cases is sufficiently low that conventional statistical significance may be difficult to obtain.

198. See supra Figure 2.

199. We define the following regions: (1) South Asia; (2) East Asia, the Pacific, and Oceania; (3) Central and Eastern Europe and Central Asia; (4) Sub-Saharan Africa; (5) North Africa and the Middle East; (6) Latin America and the Caribbean; and (7) Western Europe and North America. These classifications were borrowed from Paul Collier \& Benedikt Goderis, Commodity Prices and Growth: An Empirical Investigation, 56 EUR. ECON. REV. 1241, 1244 (2012). 
d'état. ${ }^{200}$ Table 2 compares the findings for Latin America to those of the rest of the world, while full regression results are reported in Appendix II. ${ }^{201}$ The comparison suggests that while democratic transitions are associated with right-toresist adoption both in Latin America and beyond, coups are associated with the right to resist in Latin America only. ${ }^{202}$ Thus, our overall finding that the right to resist may serve as backward-looking legitimation for coupmakers appears to be driven by this (rather substantial) subset of our data. ${ }^{203}$

TABLE2. Summary of Empirical Results

\begin{tabular}{|c|c|c|}
\hline Variable & Latin America & Rest \\
\hline Democratic Transition & Positive* & Positive ${ }^{* *}$ \\
\hline Democracy & Insignificant & Positive* \\
\hline Coup in Last Four Years & Positive $* * *$ & Insignificant \\
\hline Energy Consumption per Capita & Positive ${ }^{* * * *}$ & Insignificant \\
\hline Global Adoption in Previous Year & Negative ${ }^{*}$ & Insignificant \\
\hline Regional Adoption in Previous Year & Insignificant & Insignificant \\
\hline Number of Coups in Nation's History & Insignificant & Positive* \\
\hline
\end{tabular}

There are different possible interpretations for this finding. One is simply that Latin American constitutionalism has always been characterized by instability and dictatorship, thus providing Latin American nations with a fertile ground to reinvent the right to resist differently from its traditional conceptualizations in political theory. ${ }^{204}$ Another explanation is that Latin American constitutionalism has always had its own distinct trajectory that started long before constitution-

200. We also found that in some regions neither variable had any statistically significant effect at all, presumably because there were hardly any cases of right-to-resist adoption.

201. The following countries are considered part of the Latin America region for purposes of this analysis: Argentina, Belize, Bolivia, Brazil, Chile, Colombia, Costa Rica, Ecuador, El Salvador, Guatemala, Guyana, Honduras, Mexico, Nicaragua, Panama, Paraguay, Peru, Suriname, Uruguay, and Venezuela. Limiting the sample to Latin America reduces the number of country-year observations from 8176 to 1722 . The smaller sample is still large enough to allow us to reach statistical conclusions.

202. In fact, after a coup d'état, the probability that a Latin American country adopts a right to resist increases by 2.2 percentage points in each year (as compared to 0.8 percentage points in the world at large).

203. About 40 percent of all cases of right-to-resist adoption took place in Latin America.

204. See, e.g., Keith S. Rosenn, The Success of Constitutionalism in the United States and Its Failure in Latin America: An Explanation, 22 U. MIAMI INTER-AM. L. REV. 1, 6-7, 27 (1990) (describing the instability of Latin America constitutionalism as shown by the fact that "since independence the twenty Latin American republics have promulgated some 253 constitutions, an average of 12.65 per country" and discussing possible explanations for this, among them that "Latin America has been slow in developing institutions to check the arbitrary abuse of executive power"). 
alism in most of the rest of the world, a constitutionalism that was often characterized by extensive borrowing from other nations, particularly the United States and other Latin American countries. ${ }^{205}$ Dictators may have drawn inspiration from one another, causing certain rights to spread throughout Latin America. As part of a distinct Latin American constitutional trajectory, Latin American countries have developed a form of regional hyper-constitutionalism, and this may lead to more numerous and ambitious changes in constitutions generally which, when taken in conjunction with the fact that the right to resist is rarely removed from subsequent rewrites after an initial introduction, may prove decisive. ${ }^{206}$ Finally, as yet another explanation, the fact that all Latin American countries operate in the civil law legal tradition, rather than the common law legal tradition, ${ }^{207}$ may make them more likely to embrace a conception of the right to resist that is different from its traditional conception in political theory.

This latter possibility may require some further explanation. There are numerous important differences between the common and civil law legal traditions, most of which have been thoroughly documented in the literature. ${ }^{208}$ One of these differences, specifically in the constitutional realm in which the boundaries between the traditions are less clear, ${ }^{209}$ concerns the seemingly competing tradi-

205. See, e.g., GEORGE ATHAN BILLIAS, AMERICAN CONSTITUTIONALISM HEARD ROUND THE WORLD, 1776-1989: A GLOBAL PERSPECTIVE 105 (2009) (noting that some "Latin American constitutionalists ... emulate[d] North American ideas and institutions," even copying "word for word from the U.S. Constitution"); Zachary Elkins, Constitutional Networks, in NETWORKED POLITICS: AGENCY, POWER, AND GOVERNANCE 43, 43 (Miles Kahler ed., 2009) ("Legend has it that some Latin American constitutions in the 1800s shared not only the same provisions but also the same typographical errors.").

206. See Daniel Lansberg-Rodriguez, Wiki-Constitutionalism, NEW REPUBLIC (May 25, 2010), http:// www.tnr.com/article/politics/75150/wiki-constitutionalism ("The Dominican Republic has had 32 separate constitutions since its independence in 1821 . Venezuela follows close behind with 26, Haiti has had 24, Ecuador 20, and Bolivia recently passed its seventeenth. In fact, over half of the 21 Latin American nations have had at least ten constitutions while, in the rest of the world, only Thailand (17), France (16), Greece (13), and Poland (10) have reached double digits.").

207. See JOHn Henry Merryman \& Rogelio PÉREZ-PERDOMO, THE CiVIL LAWTRAdition: AN INTRODUCTION TO THE LEGAL SYSTEMS OF EUROPE AND LATIN AMERICA 3 (3d ed. 2007) (noting that the civil law tradition is "the dominant legal tradition in Europe" and "all of Latin America").

208. The common law system is usually characterized by a reliance on case law and precedent; an adversarial system of criminal procedure; and a high profile judiciary that emphasizes the individual judge. The civil law system, in contrast, is said to rely heavily on codes, especially the civil code; uses an inquisitorial system of criminal procedure; and employs judges in a hierarchical bureaucratic structure. See generally id. at 1-90 (offering an introduction to the basics of the civil law tradition).

209. See Lorraine E. Weinrib, The Postwar Paradigm and American Exceptionalism, in THE MigRATION OF CONSTITUTIONAL IDEAS 84, 89-90 (Suijt Choudhry ed., 2006) (describing the post-war paradigm of constitutional protection of equal citizenship and human dignity, enforced through judicial review and how "[t]his shared remedial project has broken down hitherto imper- 
tional conceptualizations of the social contract. ${ }^{210}$ In particular, within the common law tradition, the Lockean social contract is of more limited scope, wherein a people delegate certain well-defined powers to their government but retain a residual power that can be used to overthrow the government. ${ }^{211}$ In the civil law tradition, however, which draws far more from the writings of Jean Jacques Rousseau than from Locke, ${ }^{212}$ the social contract is all encompassing, and people surrender individual preference to the general will and the common good. ${ }^{213}$ These different conceptions of the social contract go hand in hand with different ideas about the appropriate role of government in society. A line of research suggests that common law countries tend to be characterized by a smaller government, ${ }^{214}$ a more libertarian conception of rights, ${ }^{215}$ and a stronger belief in the free market than civil law countries. ${ }^{216}$ As such, the common law tradition fits much better with the traditional conceptualization of the right to resist in political theory than the civil law tradition. As a result, constitutionmakers within the civil law tradition, whose thoughts may lean more toward Rousseau than Locke, may find it easier to reject the traditional conceptualization of this right and give it a new meaning.

Ultimately, all of these explanations rest on some degree of speculation. It is not possible at this stage to say with any certainty why Latin American nations make different choices, though our instinct is that a pattern of intra-regional bor-

meable boundaries between separate sovereign legal systems and blurred hitherto sharp distinctions ... between constitutions based on common law and those based on civil law").

210. For a brief overview see LESAFFER, supra note 118, at 387-92.

211. See id. at 388 .

212. See, e.g., HAYEK, supra note 130, at 54-70 (describing the French and British traditions of liberty and how the French tradition is based on Rousseau while the British tradition is based on Locke); LESAFFER, supra note 118, at 392 (noting that Rousseau's writings on the social contract had great impact on the French Revolution); Paolo G. Carozza, From Conquest to Constitutions: Retrieving a Latin American Tradition of the Idea of Human Rights, 25 HUM. RTS. Q. 281, 300 (2003) (noting that the Latin American constitutional tradition is influenced by Rousseau and therefore emphasizes not only liberty but also equality and duties).

213. The French Declaration, for example, states that "[1]aw is an expression of the common will" and that "[s]ocial distinctions shall be based solely upon the public utility." DECLARATION OF THE RigHTS OF MAN AND OF THE CITIZEN OF 26 AUGUST 1789 arts. 1, 6 (Fr.), translated in 2 NiJHOFF, supra note 8, at 20-21.

214. See Rafael La Porta et al., The Economic Consequences of Legal Origins, 46 J. ECON. LITERATURE 285, 286 (2008) (noting that "civil law is associated with a heavier hand of government ownership and regulation than common law" and that "common law is associated with lower formalism of judicial procedures").

215. See Law \& Versteeg, supra note 2, at 1164 (arguing for the existence of a libertarian constitutional tradition of negative liberty and judicial process rights that is associated with the common law tradition and a statist constitutional tradition of positive social welfare rights, family rights, and duties that is associated with the civil law tradition).

216. See, e.g., Mahoney, supra note 109, at 504 ("English common law developed as it did because landed aristocrats and merchants wanted a system of law that would provide strong protections for property and contract rights and limit the Crown's ability to interfere in markets."). 
rowing is a powerful determinant. Many things may set Latin America apart from the rest of the world, and some of these attributes may be shared with other countries outside of this region. At the same time, we can say with some certainty that the right to resist is not only associated with democratic regimes but is also a tool for coupmakers. As such, the right is thus both democratic and undemocratic at the same time. Which of the motivations for this right prevails, however, depends on the polity that adopted it.

\section{The RIGHTTO RESIST IN PRACTICE}

One question that this Article has not directly addressed, but that represents an important direction for future research, is whether right-to-resist provisions actually make a difference in practice. In some cases, introducing the right to resist as an ex post justification may prove something of a Faustian bargain for the would-be autocrat. Even when such a provision might accomplish the goal of legitimating the ruler in the short term, these provisions may in time be invoked by enemies of the regime and prove instrumental to the weakening or overthrow of their creators - a constitutional equivalent to Dr. Frankenstein's monster. In other cases in which the right to resist is adopted to constrain the future, it may actually do so in practice. Regardless of its justification, smart political opponents may be able to use the right against the regime that adopted it.

Consider the following events. In 1953, a young Cuban lawyer named Fidel Castro was arrested for organizing an armed attack on a military enclave. ${ }^{217}$ In the court proceedings that followed his arrest, Castro predicated his defense on the constitutionally protected right to rebel, which had itself been enshrined into Batista's new constitution as a justification for overthrowing the previous government. ${ }^{218}$ Castro's speech itself was subsequently published as an influential pamphlet titled History Will Absolve Me and included the following passage: "Cuba is suffering from a cruel and base despotism. You are well aware that resistance to despots is legitimate. This is a universally recognized principle and our 1940 Constitution expressly makes it a sacred right, in the second paragraph of Article 40." ${ }^{219}$ Castro succeeded in harnessing his legal knowledge and personal charisma, turning his defense into a searing and very public indictment of the excesses

217. See MARJORIE S. ZATZ, PRODUCING LEGALITY: LAW AND SOCIALISM IN CUBA 123 (1994) (discussing how Fidel Castro's professional training in law "helped him prepare his eloquent selfdefense following his arrest in 1953 for the rebel raid on the Moncada Barracks").

218. See ANTONIO RAFAEl De la COVA, THE MonCADA ATtACK: BiRTH OF THE CubAN REVOLUTION 230 (2007) (discussing Castro's trial and legal defense following the Moncada attack).

219. Fidel Castro, Speech in His Defense at Trial: History Will Absolve Me (Oct. 16, 1953), available at http://www.marxists.org/history/cuba/archive/castro/1953/10/16.htm (last visited Mar. 6, 2012). 
of the ruling regime. ${ }^{220}$ While eventually found guilty in a split 2-1 decision, Castro's trial and two years' imprisonment were instrumental in elevating the young rebel into an international figure. ${ }^{221}$

Left-wing and right-wing governments may find that the right to resist has unintended consequences. When, in 2002, the historically divided and ineffective Venezuelan opposition unexpectedly found itself poised to overthrow the Hugo Chavez regime following a brutal crackdown on peaceful protesters, the president expressed concern that Article 350 of the 1999 Constitution, whose drafting and inclusion he had overseen himself, might be used as justification for removing him. ${ }^{22}$ These fears proved prescient when, with over one million protesters amassed outside the Miraflores presidential palace in Caracas, the Venezuelan armed forces began to abandon Chavez. General Efraín Vásquez Velasco, the first among the top brass to do so, explained his decision as follows: "Mister President, I was loyal until the end, but the violation of human rights and the killing that took place today cannot be tolerated. I evoke articles, 25, 328 and 350 of the Constitution of the Bolivarian Republic of Venezuela which oblige me to make this decision." 223

An ocean away in Ghana, an entrenched Jerry Rawlings struggled to maintain de facto control of a rapidly liberalizing nation early in 2000. The constitutional right to resist, introduced by Rawlings's government itself following its unconstitutional seizure of power, cropped up unexpectedly to frustrate a coup. As reported by Thomas Friedman for the New York Times, following Rawlings's removal from office:

"On the day of the elections there was a polling station in Accra where soldiers started destroying voting boxes," recalled Joseph Ebo Quarshie, president of the Ghana Bar Association. "Immediately, someone called an FM station and it was reported on the air. I was at my bank at the time. A guy walks up to me, a pharmacist I know, and says, 'Have you heard what's going on at this polling station in Accra? What is the Bar

220. See DE LA COVA, supra note 218, at 230 (describing the transformation of History Will Absolve Me into the "manifesto of the Cuban Revolution" and explaining its condemnation of the Batista regime's "Tenth of March Coup" and military "brutality").

221. See Benjamin KeEn \& KeIth Haynes, A History of Latin AMERicA 389 (8th ed. 2009) (discussing Castro's reputational enhancement following the Moncada attack trial, defense, and imprisonment).

222. See Brian A. Nelson, The Silence and the Scorpion: The Coup AgAinst Chávez AND THE MAKING OF MODERN VENEZUELA 24 (2009) (noting Chavez's worry that "the opposition, invoking article 350 of the new constitution, [could] force him from office" relying on popular feelings that "his regime was 'contrary to the values, principals [sic] and democratic ideals of the country").

223. Id. at 133 (quoting Efraín Vasquez Velasco). 
Association doing about it?' So I got in my car and turned on SKY FM. Minutes later I got a call from JOY FM. I told them to call me back in a few minutes. Meanwhile, I got a copy of the Constitution. JOY FM called me back and I read over the radio the article in the Constitution which says that citizens had the right to resist interference in a polling station. JOY FM kept playing my interview over and over. A couple of hours later the soldiers were chased off by voters." 224

Rawlings's handpicked successor lost the election, and a new era for democratic Ghana began. 225

When the right to resist is adopted to constrain the future, it may also have important real-world consequences. In February 2012, the first democratically elected president of the Maldives, Mohamed Nasheed, resigned from office after losing the support of the nation's powerful police force. ${ }^{226}$ Nasheed had been elected under a constitutional system that was adopted in 2008 in the wake of a thirty-year dictatorship that preceded it. This constitution provided for a right both for the citizenry and for the national security services to resist illegal orders. ${ }^{227}$ These provisions reflected what we have called the forward-looking logic of the right, designed to protect against democratic backsliding. Interestingly, they were first used against Nasheed himself, though it was his political allies that had argued for the adoption of these provisions in the first place. ${ }^{228}$ Yet when Nasheed found himself frustrated by an opposition-controlled parliament and turned increasingly to unconstitutional tactics, including the arrest of opponents in defiance of court orders, he found himself on the wrong end of the right. A series of escalating protests in early 2012 led to increasing police frustration, and on February 7, invoking the constitution, police called for Nasheed's resignation. Dictators, it seems, are not the only ones who find that the right to resist is a double-edged sword.

224. Thomas L. Friedman, Foreign Affairs; Low-Tech Democracy, N.Y. TIMES, May 1, 2001, http:// www.nytimes.com/2001/05/01/opinion/foreign-affairs-low-tech-democracy.html.

225. Id. (discussing how FM radios helped “J. A. Kufuor, a free-market democrat, to defeat Mr. Rawlings's tired, floundering party" in the December 2000 elections).

226. REPORT OF THE COMMISSION OF NATIONAL INQUIRY, MALDIVES (2012), available at http:// dhirls.net/DhiRLS/ebooks/CONI-Report\%20(2012)\%20eBook-DhiRLS.pdf.

227. CONST. art. 64 (Maldives), translated in FUNCTIONAL TRANSLATION OFTHE CONSTITUTION OF THE REPUBLIC OF MALDIVES 2008 (Dheena Hussain trans., 2008) ("No employee of the State shall impose any orders on a person except under authority of a law. Everyone has the right not to obey an unlawful order."); id. art. 245 ("No person shall give an illegal order to a member of the security services. Members of the security services shall not obey a manifestly illegal order.").

228. Interview with Mohamed Didi, Member of Maldives Constitutional Drafting Commission, in Sing. (Aug. 19, 2012). 
These anecdotes suggest that the right to resist can be a dangerous one for autocrats who invoke it to justify their rule. Even when it is not adopted to constrain the future but to legitimate the past, the right to resist may motivate regime opponents later on. Such opponents must overcome formidable collective action problems: They must agree on what behavior constitutes a legitimate trigger for protest, and they must coordinate the place and timing of group action. The right to resist provides clear language around which citizens can coordinate their behavior.

The dissidents of the Arab Spring were able to throw off their regimes despite a complete absence of institutional support or constitutional validation. When Mohamed Bouazizi, the Tunisian street vendor, set himself on fire following the confiscation of his peddling merchandise, he acted primarily in response to personal humiliation rather than as a catalyst for regime change. ${ }^{229}$ Yet his act of self-sacrifice served as a tipping point, uniting alienated Arab populations and providing a rallying point for overcoming the severe collective action challenges. At their best, constitutional right-to-resist provisions seek to trigger similar results without necessitating this level of uncommonly dramatic sacrifice.

Within this international context, the importance of understanding the rise of constitutional provisions that actually mandate this kind of action-the right to resist-could not be greater. Hopefully, this study will draw attention to the existence and possible importance of these mechanisms and begin a timely, scholarly conversation on the subject.

\section{CONCLUSION}

This Article seeks to understand the origins and spread of the right to resist. Drawing on original data, based on the coding of all written constitutions adopted since 1781, we find that no less than 20 percent of all constitutions today contain some version of the right to resist and that there has been a marked increase in the introduction of this right during recent decades.

As to the question of why it is, exactly, that constitutionmakers would willingly empower their people to overthrow the government in the first place, we set forth two possible explanations. First, and in line with a longstanding tradition in political theory, we theorize that the right to resist is adopted as a forwardlooking democratic precommitment device that enables the people to act as the

229. Rania Abouzeid, Bouazizi: The Man Who Set Himself and Tunisia on Fire, TIME, Jan. 21, 2011, http:/www.time.com/time/magazine/article/0,9171,2044723,00.html (quoting Bouazizi's mother as saying, "Mohammed did what he did for the sake of his dignity" (internal quotation marks omitted)). 
ultimate enforcer of democratic rule. Second, and perhaps more troubling, we speculate that this right might actually be fundamentally undemocratic and adopted as a backward-looking legitimation of the action of coupmakers. When testing these theories against each other, we found empirical evidence to support both: Countries are more likely to adopt the right to resist in democratic regimes and in the aftermath of both democratic transitions and coups d'etat. Which of the two explanations prevails depends on the national context and is open to some speculation, although we found some evidence that it is mainly the countries in Latin America that adopt this right after a coup d'état.

Our finding that the right to resist can serve two quite different purposes goes some way toward advancing our understanding of constitutions in a broader sense. The common belief is that constitutions are typically adopted to bind the future on behalf of the present. Yet our findings show that, in some cases, they also function as a reinterpretation or justification of the past. This function is largely foreign to constitutional theory today, even though it fits with an older constitutional tradition that predates Enlightenment thought. Our findings suggest that this older tradition is still of empirical relevance today and that contemporary constitutional theory should perhaps pay more attention to this backward-looking, historically oriented role of constitutions. 


\section{APPENDIXI: FULL TEXT OF ALL(HISTORICAL) CONSTITUTIONAL RIGHT- TO-RESIST PROVISIONS}

\begin{tabular}{|c|c|l|}
\hline Adopted & $\begin{array}{c}\text { Lasted } \\
\text { Until }\end{array}$ & \multicolumn{1}{c|}{ Full Text of the Relevant Provision(s) } \\
\hline $\begin{array}{c}\text { Algeria } \\
1976\end{array}$ & Current & $\begin{array}{l}\text { Article 27: Algeria associates itself with all the peoples fighting } \\
\text { for their political and economic liberation, for the right of self- } \\
\text { determination and against any racial discrimination. } \\
\text { Article 33: Individual or associative defense of the fundamental } \\
\text { human rights and individual and collective liberties is guaranteed. }\end{array}$ \\
\hline Argentina & Current & $\begin{array}{l}\text { Article 36: This Constitution shall remain in force even if its } \\
\text { observance is interrupted by acts of force against the institu- } \\
\text { tional order and the democratic system. Such acts shall be ir- } \\
\text { revocably void. } \\
\text { W. } \\
\text { Those who, as a consequence of these acts, were to assume } \\
\text { the powers foreseen for the authorities of this Constitution or } \\
\text { for those of the provinces shall be punished with the same pen- } \\
\text { alties and shall be civil and criminally liable for their acts. The } \\
\text { respective actions shall not be subject to prescription. } \\
\text { All citizens have the right to oppose resistance to those } \\
\text { committing the acts of force described in this section. }\end{array}$ \\
\hline Armenia & Current & $\begin{array}{l}\text { Article 18: Everyone shall have a right to protect his/her rights } \\
\text { and freedoms by any means not prohibited by the law. }\end{array}$ \\
\hline Current & $\begin{array}{l}\text { Article 54 (2): Every citizen of the Azerbaijan Republic has the } \\
\text { right to independently show resistance to the attempt of a mu- } \\
\text { tiny against the State or forced change of the constitutional } \\
\text { order. }\end{array}$ \\
\hline
\end{tabular}




\begin{tabular}{|c|c|c|}
\hline Adopted & $\begin{array}{c}\text { Lasted } \\
\text { Until }\end{array}$ & Full Text of the Relevant Provision(s) \\
\hline $\begin{array}{c}\text { Benin } \\
1990\end{array}$ & Current & $\begin{array}{l}\text { Article 66: In case of a coup d'état, of a putsch, of aggression by } \\
\text { mercenaries or of any action by force whatsoever, any member } \\
\text { of a constitutional agency shall have the right and the duty to } \\
\text { make an appeal by any means in order to re-establish the con- } \\
\text { stitutional legitimacy, including recourse to existing agree- } \\
\text { ments of military or defense co-operation. In these circum- } \\
\text { stances for any Beninese to disobey and organize himself to } \\
\text { put a check to the illegitimate authority shall constitute the } \\
\text { most sacred of rights and the most imperative of duties. }\end{array}$ \\
\hline $\begin{array}{c}\text { Burkina } \\
\text { Faso } 1991\end{array}$ & Current & $\begin{array}{l}\text { Article 167: The source of all legitimacy arises from the } \\
\text { present Constitution. } \\
\text { All power which does not take its source from this Con- } \\
\text { stitution, notably those stemming from a coup d'état or from } \\
\text { a putsch, shall be illegal. In this case, the right to civil disobe- } \\
\text { dience shall be recognized to all the citizens. }\end{array}$ \\
\hline $\begin{array}{l}\text { Cape } \\
\text { Verde } \\
1996\end{array}$ & Current & $\begin{array}{l}\text { Article 18: Any citizen shall have the right not to obey any } \\
\text { order that offends his right, liberties and guarantees and to } \\
\text { resist by force any illegal aggression, when the recourse to the } \\
\text { public authority is not possible. }\end{array}$ \\
\hline $\begin{array}{l}\text { Chad } \\
1996\end{array}$ & Current & $\begin{array}{l}\text { Preamble: We the Chadian people:... } \\
\ldots . \\
\text { _.Proclaim solemnly our right and duty to resist and } \\
\text { disobey any individual or group of individuals, any corps } \\
\text { of State that would assume power by force or would ex- } \\
\text { ercise it in violation of the present Constitution; } \\
\text { —Affirm our total opposition to any regime whose poli- } \\
\text { cy would be founded on the arbitrariness, dictatorship, } \\
\text { injustice, corruption, extortion, nepotism, clanism, trib- } \\
\text { alism, confessionalism, or confiscation of power; } \\
\ldots \quad \text {... Adopt solemnly the present Constitution as the su- } \\
\text { preme law of the State. } \\
\text { This Preamble is an integral part of the Constitution. }\end{array}$ \\
\hline
\end{tabular}




\begin{tabular}{|c|c|c|}
\hline Adopted & $\begin{array}{c}\text { Lasted } \\
\text { Until }\end{array}$ & \multicolumn{1}{c|}{ Full Text of the Relevant Provision(s) } \\
\hline $\begin{array}{c}\text { Congo } \\
\text { (Brazzaville }\end{array}$ & 2002 & $\begin{array}{l}\text { Preamble: [Proclaim] The right and obligation of every citizen } \\
\text { to resist by civil disobedience upon the default of other re- } \\
\text { courses, no matter what enterprise to overthrow the consti- } \\
\text { tutional regime, to take power by a coup d'état or exercise in a } \\
\text { tyrannical manner. }\end{array}$ \\
\hline $\begin{array}{c}\text { Congo } \\
\text { (DR) }\end{array}$ & Current & $\begin{array}{l}\text { Article } 64: \text { All Congolese have the duty to oppose any indivi- } \\
\text { dual or group of individuals who seize power by force or who } \\
\text { exercise it in violation of the provisions of this Constitution. }\end{array}$ \\
\hline $\begin{array}{c}\text { Cuba } \\
1940\end{array}$ & 1959 & $\begin{array}{l}\text { Article 40: Legal or administrative provisions, or those of any } \\
\text { other kind, which regulate the exercise of the rights which } \\
\text { this Constitution guarantees, shall be null if they diminish, } \\
\text { restrict, or impair them. Adequate resistance for the protec- } \\
\text { tion of the individual rights above guaranteed is legitimate. } \\
\text { The right of action to prosecute infractions of this Title } \\
\text { is public, without surety or formality of any kind, and by a } \\
\text { simple denunciation. } \\
\text { The enumeration of the rights guaranteed in this Title } \\
\text { does not exclude the others that this Constitution establishes, } \\
\text { or others of analogous nature or that are derived from the } \\
\text { principle of the sovereignty of the people and from the repub- } \\
\text { lican form of government. }\end{array}$ \\
\hline
\end{tabular}




\begin{tabular}{|l|l|l|}
\hline Adopted & $\begin{array}{c}\text { Lasted } \\
\text { Until }\end{array}$ & \multicolumn{1}{c|}{ Full Text of the Relevant Provision(s) } \\
\hline Cuba & $\begin{array}{l}\text { Article 3: In the Republic of Cuba sovereignty lies in the } \\
\text { people, from whom originates all the power of the state. That } \\
\text { power is exercised directly or through the assemblies of People's } \\
\text { Power and other state bodies which derive their authority from } \\
\text { these assemblies, in the form and according to the norms es- } \\
\text { tablished in the Constitution and by law. } \\
\text { When no other recourse is possible, all citizens have the } \\
\text { right to resist through all means, including armed struggle, } \\
\text { anyone who tries to overthrow the political, social and eco- } \\
\text { nomic order established in this Constitution. } \\
\text { Socialism, as well as the revolutionary political and social } \\
\text { system established by this Constitution, has been forged dur- } \\
\text { ing years of heroic resistance to the aggression of every kind } \\
\text { and economic war waged by the governments of the most } \\
\text { powerful imperialist states that have ever existed; it has dem- } \\
\text { onstrated its ability to transform the nation and create an } \\
\text { entirely new and just society, and is irrevocable: Cuba will } \\
\text { never revert to capitalism. } \\
\text { Article 12: The Republic of Cuba espouses the principles of } \\
\text { anti-imperialism and internationalism, and } \\
\text { (a) ratifies its aspirations to a valid, true and dignified } \\
\text { peace for all states, big or small, weak or powerful, based } \\
\text { on respect for the independence and sovereignty of the } \\
\text { peoples and the right to self-determination; } \\
\text { \% } \\
\text { (g) categorizes the war of aggression and conquest as an } \\
\text { international crime, recognizes the legitimacy of strug- } \\
\text { gles for national liberation, as well as armed resistance to } \\
\text { aggression, and considers its internationalist obligation } \\
\text { to support those attacked and [stand] with the peoples } \\
\text { who fight for their liberation and self-determination ... }\end{array}$ \\
\hline
\end{tabular}




\begin{tabular}{|c|c|c|}
\hline Adopted & $\begin{array}{c}\text { Lasted } \\
\text { Until }\end{array}$ & Full Text of the Relevant Provision(s) \\
\hline $\begin{array}{l}\text { Czech } \\
\text { Republic } \\
1993\end{array}$ & Current & $\begin{array}{l}\text { Article 23: Citizens have the right to put up resistance to any } \\
\text { person who would do away with the democratic order of hu- } \\
\text { man rights and fundamental freedoms established by this } \\
\text { Charter, if the actions of constitutional institutions or the ef- } \\
\text { fective use of legal means have been frustrated. }\end{array}$ \\
\hline $\begin{array}{l}\text { Dominican } \\
\text { Republic } \\
1963\end{array}$ & 1966 & $\begin{array}{l}\text { Article 81: Declared legitimate is resistance directed toward } \\
\text { the protection of human rights detailed above, which do not } \\
\text { exclude such others as this Constitution establishes, nor others } \\
\text { of-the same nature or that may result from the sovereignty } \\
\text { of the- people and of the democratic regime. }\end{array}$ \\
\hline $\begin{array}{l}\text { Dominican } \\
\text { Republic } \\
1966\end{array}$ & Current & $\begin{array}{l}\text { Article 8(5): No person is obligated to comply with what is not } \\
\text { required by law; nor can they legitimately be impeded from } \\
\text { actions not prohibited by law. } \\
\text { Article 46: All laws, decrees, resolutions, regulations or acts are } \\
\text { null and void if contrary to the rights in this constitution. } \\
\text { Article 99: All usurped State Authority is null. }\end{array}$ \\
\hline $\begin{array}{c}\text { Ecuador } \\
1978\end{array}$ & 1998 & $\begin{array}{l}\text { Article 4: The Ecuadoran State condemns all forms of coloni- } \\
\text { alism, neocolonialism and racial discrimination or segregation. } \\
\text { It recognizes the right of peoples to liberate themselves from } \\
\text { these oppressive systems. }\end{array}$ \\
\hline $\begin{array}{c}\text { Ecuador } \\
1998\end{array}$ & 2008 & $\begin{array}{l}\text { Article 4(6): [Ecuador] rejects all forms of colonialism, neoco- } \\
\text { lonialism, and discrimination and recognizes the right of the } \\
\text { people for self-determination and freedom from oppressive } \\
\text { systems. }\end{array}$ \\
\hline $\begin{array}{c}\text { Ecuador } \\
2008\end{array}$ & Current & $\begin{array}{l}\text { Article 98: Individuals and groups may exercise the right of } \\
\text { resistance against acts or omissions of public authorities, per- } \\
\text { sons or legal entities that may violate or infringe their consti- } \\
\text { tutional rights, and demand the recognition of new rights. } \\
\text { Article } 416(8) \text { : The Ecuadoran State condemns all forms of } \\
\text { colonialism, neocolonialism and racial discrimination or segre- } \\
\text { gation. It recognizes the right of peoples to liberate themselves } \\
\text { from these oppressive systems. }\end{array}$ \\
\hline
\end{tabular}




\begin{tabular}{|c|c|l|}
\hline Adopted & $\begin{array}{c}\text { Lasted } \\
\text { Until }\end{array}$ & \multicolumn{1}{|c|}{ Full Text of the Relevant Provision(s) } \\
\hline $\begin{array}{c}\text { E1 } \\
\text { Salvador }\end{array}$ & 1986 & $\begin{array}{l}\text { Article 8: Salvador recognizes rights and obligations anterior } \\
\text { and superior to the positive laws, derived from the principles } \\
\text { of liberty, equality, and fraternity; and as fundamental bases, } \\
\text { family ties, labor, property, and public order. } \\
\text { Article 9: Every inhabitant of Salvador holds the incontestable } \\
\text { right to preserve and defend his life, liberty, and property, and } \\
\text { to freely dispose of his belongings in conformity with law. }\end{array}$ \\
\hline $\begin{array}{c}\text { E1 } \\
1945\end{array}$ & $\begin{array}{l}\text { Article 36: The right of insurrection shall produce in no case } \\
\text { the abrogation of the laws, and its effects shall be limited to } \\
\text { removing, as may prove necessary, the government officials } \\
\text { who exercise authority, and appointing pro tempore those who } \\
\text { shall fill their places until the regular appointments are made } \\
\text { in the manner established by the Constitution. }\end{array}$ \\
\hline $\begin{array}{c}\text { El } \\
\text { Salvador }\end{array}$ & 1950 & $\begin{array}{l}\text { Article 5: The succession of the presidency is essential to the } \\
\text { maintenance of the form of the established government. The } \\
\text { violation of this standard shall oblige an insurrection. } \\
\text { Article 175: The right to insurrection, which the Constitution } \\
\text { recognizes, in no case may produce the abrogation of laws; it } \\
\text { is limited in its separatory effects, when necessary, to officials, } \\
\text { while it may be substituted it in the legal method. }\end{array}$ \\
\hline
\end{tabular}




\begin{tabular}{|c|c|c|}
\hline Adopted & $\begin{array}{c}\text { Lasted } \\
\text { Until }\end{array}$ & Full Text of the Relevant Provision(s) \\
\hline $\begin{array}{c}\text { El } \\
\text { Salvador } \\
1996\end{array}$ & Current & $\begin{array}{l}\text { Article 87: The right of the people to insurrection is recog- } \\
\text { nized, for the sole object of reestablishing constitutional order } \\
\text { altered by the transgression of the norms relative to the form } \\
\text { of government or to the established political system, or for } \\
\text { serious violations of the rights consecrated in this Consti- } \\
\text { tution. } \\
\text { The exercise of this right shall not produce the abroga- } \\
\text { tion nor the reform of this Constitution, and shall be limited } \\
\text { to the removal insofar as necessary of transgressing officials, } \\
\text { replacing them in a transitory manner until they are substi- } \\
\text { tuted in the form established by this Constitution. } \\
\text { Under no circumstances shall the powers and jurisdic- } \\
\text { tions which correspond to the fundamental organs established } \\
\text { by this Constitution be exercised by the same person or by a } \\
\text { sole institution. } \\
\text { Article } 88 \text { : The principle that a President cannot succeed } \\
\text { himself [alternabilidad] is indispensable for the maintenance } \\
\text { of the established form of government and political system. } \\
\text { Violation of this norm makes insurrection an obligation. }\end{array}$ \\
\hline $\begin{array}{c}\text { Estonia } \\
1992\end{array}$ & Current & $\begin{array}{l}\text { Article } 54 \text { (2): Where no other means are available, every } \\
\text { Estonian citizen shall have the right to initiate spontaneous ac- } \\
\text { tion against any forcible change of the constitutional system. }\end{array}$ \\
\hline $\begin{array}{c}\text { France } \\
1791\end{array}$ & $\begin{array}{l}\text { 1795; } \\
\text { Reinstated } \\
\text { 1958- } \\
\text { (Current) }\end{array}$ & $\begin{array}{l}\text { Article 2: The aim of all political association is the preservation } \\
\text { of the natural and imprescriptible rights of man. These rights } \\
\text { are liberty, property, security, and resistance to oppression. }\end{array}$ \\
\hline $\begin{array}{c}\text { Germany } \\
1968\end{array}$ & Current & $\begin{array}{l}\text { Article } 20 \text { (4): All Germans shall have the right to resist any } \\
\text { persons seeking to abolish this constitutional order, if no other } \\
\text { remedy is available. }\end{array}$ \\
\hline
\end{tabular}




\begin{tabular}{|c|c|c|}
\hline Adopted & $\begin{array}{c}\text { Lasted } \\
\text { Until }\end{array}$ & Full Text of the Relevant Provision(s) \\
\hline $\begin{array}{c}\text { Ghana } \\
1979\end{array}$ & 1992 & $\begin{array}{l}\text { Article 1(3): All citizens of Ghana shall have the right to resist } \\
\text { any person or persons seeking to abolish the constitutional or- } \\
\text { der as established by this Constitution should no other reme- } \\
\text { dy be possible. }\end{array}$ \\
\hline $\begin{array}{c}\text { Ghana } \\
1992\end{array}$ & Current & $\begin{array}{l}\text { Article 3(4): All citizens of Ghana shall have the right and duty } \\
\text { at all times- } \\
\text { (a) to defend this Constitution, and in particular, to resist } \\
\text { any person or group of persons seeking to commit any of } \\
\text { the acts referred to in clause (3) of this article; and } \\
\text { (b) to do all in their power to restore this Constitution af- } \\
\text { ter it has been suspended, overthrown, or abrogated as } \\
\text { referred to in clause (3) of this article. } \\
\text { Article 3(5): Any person or group of persons who suppresses or } \\
\text { resists the suspension, overthrow or abrogation of this Con- } \\
\text { stitution as referred to in clause (3) of this article, commits no } \\
\text { offence. } \\
\text { Article 3(6): Where a person referred to in clause (5) of this } \\
\text { article is punished for any act done under that clause, the pun- } \\
\text { ishment shall, on the restoration of this Constitution, be taken } \\
\text { to be void from the time it was imposed and he shall, from that } \\
\text { time, be taken to be absolved from all liabilities arising out of } \\
\text { the punishment. } \\
\text { Article 3(7): The Supreme Court shall, on application by or } \\
\text { on behalf of a person who has suffered any punishment or loss } \\
\text { to which clause (6) of this article relates, award him adequate } \\
\text { compensation, which shall be charged on the Consolidated } \\
\text { Fund, in respect of any suffering or loss incurred as a result of } \\
\text { the punishment. }\end{array}$ \\
\hline $\begin{array}{c}\text { Greece } \\
1975\end{array}$ & Current & $\begin{array}{l}\text { Article 120.4: Observance of the constitution is entrusted to } \\
\text { the patriotism of the Greeks who shall have the right and the } \\
\text { duty to resist by all possible means whoever attempts the vio- } \\
\text { lent abolition of the Constitution. }\end{array}$ \\
\hline
\end{tabular}




\begin{tabular}{|c|c|c|}
\hline Adopted & $\begin{array}{c}\text { Lasted } \\
\text { Until }\end{array}$ & \multicolumn{1}{c|}{ Full Text of the Relevant Provision(s) } \\
\hline Guatemala & 1965 & $\begin{array}{l}\text { Article 50: Legal, governmental, or other provisions which } \\
\text { regulate the exercise of the rights guaranteed by this Consti- } \\
\text { tution shall be null ipso jure if they diminish, restrain, or alter } \\
\text { them. Acts and contracts which violate constitutional stan- } \\
\text { dards shall also be null ipso jure. } \\
\text { Adequate resistance for the protection of the individual } \\
\text { rights above guaranteed is legitimate. The action to prosecute } \\
\text { infractions of the principles of this Title is public and may be } \\
\text { brought without bond or formality of any kind by a simple } \\
\text { denunciation. } \\
\text { The enumeration of the rights guaranteed in this Title } \\
\text { does not exclude others established by this Constitution or } \\
\text { others or [sic] an analogous nature or which derive from the } \\
\text { principle of the sovereignty of the people, the republican and } \\
\text { democratic form of government, and the dignity of man. }\end{array}$ \\
\hline 1945 & 1982 & $\begin{array}{l}\text { Article 77: The rights and guarantees granted by the Consti- } \\
\text { tution do not exclude others which, although not expressly } \\
\text { indicated therein, are inherent in the human person. } \\
\text { Laws and governmental orders or those of any other kind } \\
\text { that regulate the exercise of rights guaranteed by the Consti- } \\
\text { tution shall be null and void ipso jure if they diminish, restrict, } \\
\text { or distort such rights. }\end{array}$ \\
\hline $\begin{array}{l}\text { Greamble: . the Army of Guatemala, in fulfillment of its ob- } \\
\text { ligations to the Nation, echoing the feelings of the people and } \\
\text { seeking to safeguard the national honor, deposed the ruling } \\
\text { regime, the outgrowth of a system completely oblivious of le- } \\
\text { gality that brought the country into a state of anarchy and in- } \\
\text { ternational isolation which with disregard of human life, of } \\
\text { honesty in the management of public affairs, and of the rights } \\
\text { of citizens, culminated in an election vitiated by fraud. }\end{array}$ \\
\hline 1965
\end{tabular}




\begin{tabular}{|c|c|c|}
\hline Adopted & $\begin{array}{c}\text { Lasted } \\
\text { Until }\end{array}$ & Full Text of the Relevant Provision(s) \\
\hline $\begin{array}{c}\text { Guatemala } \\
1985\end{array}$ & Current & $\begin{array}{l}\text { Article 5: Any person has the right to do whatever the law does } \\
\text { not prohibit; he is not obligated to obey orders not based on } \\
\text { the law or issued according to it. Neither can he be harassed or } \\
\text { persecuted for his opinions or for acts that do not involve vio- } \\
\text { lation of same. } \\
\text { Article 45: Action to prosecute the violators of human rights is } \\
\text { public and can be exercised through a simple denunciation, } \\
\text { without any guarantee or formality whatever. The opposition } \\
\text { of the people to protect and defend the rights and guarantees } \\
\text { granted in the Constitution is legitimate. }\end{array}$ \\
\hline $\begin{array}{c}\text { Guinea } \\
1990\end{array}$ & 2010 & $\begin{array}{l}\text { Article 19: The people of Guinea shall freely and sovereignly } \\
\text { determine its institutions and the economic and social organ- } \\
\text { ization of the Nation. } \\
\text { They shall have an inalienable right to its resources. These } \\
\text { shall benefit all the citizens in an equitable fashion. } \\
\text { They shall have the right to the preservation of their heri- } \\
\text { tage, culture and environment. } \\
\text { They shall have the right to resist oppression. }\end{array}$ \\
\hline $\begin{array}{c}\text { Guinea } \\
2010\end{array}$ & Current & $\begin{array}{l}\text { Article 21: The people of Guinea shall freely and sovereignly } \\
\text { determine its institutions and the economic and social organ- } \\
\text { ization of the Nation. } \\
\text { They shall have an inalienable right to its resources. These } \\
\text { shall benefit all the citizens in an equitable fashion. } \\
\text { They shall have the right to the preservation of their her- } \\
\text { itage, culture and environment. } \\
\text { They shall have the right to resist oppression. }\end{array}$ \\
\hline $\begin{array}{c}\text { Honduras } \\
1957\end{array}$ & 1982 & $\begin{array}{l}\text { Article 4: No immediate reelection (alternabilidad) in the ex- } \\
\text { ercise of the Presidency of the Republic is compulsory. Vio- } \\
\text { lation of this rule gives the right to popular insurrection. }\end{array}$ \\
\hline
\end{tabular}




\begin{tabular}{|c|c|c|}
\hline Adopted & $\begin{array}{c}\text { Lasted } \\
\text { Until }\end{array}$ & Full Text of the Relevant Provision(s) \\
\hline $\begin{array}{c}\text { Honduras } \\
1982\end{array}$ & Current & $\begin{array}{l}\text { Article 3: No one owes obedience to a usurping government } \\
\text { nor to those who assume office or public service by force of arms } \\
\text { or by using means or procedures which violate or ignore the } \\
\text { provisions established by this Constitution and other laws. The } \\
\text { acts adopted by such authorities are null. The people have the } \\
\text { right to resort to insurrection in defense of the constitutional } \\
\text { order. }\end{array}$ \\
\hline $\begin{array}{c}\text { Hungary } \\
2011\end{array}$ & Current & $\begin{array}{l}\text { Article } C \text { : (1) The functioning of the Hungarian state is based } \\
\text { on the principle of the separation of powers. (2) Nobody may } \\
\text { direct their activity at the acquisition or exercise of public au- } \\
\text { thority by force, or seek its exclusive possession. Everyone shall } \\
\text { have the right and obligation to resist by lawful means such } \\
\text { attempts. (3) Only state authorities shall have the exclusive } \\
\text { right to use force in order to enforce the Constitution and laws. }\end{array}$ \\
\hline $\begin{array}{c}\text { Lithuania } \\
1992\end{array}$ & Current & $\begin{array}{l}\text { Article 3: No one may limit or restrict the sovereignty of the } \\
\text { People or make claims to the sovereign powers of the People. } \\
\text { The People and each citizen shall have the right to oppose } \\
\text { anyone who encroaches on the independence, territorial inte- } \\
\text { grity, or constitutional order of the State of Lithuania by force. }\end{array}$ \\
\hline $\begin{array}{c}\text { Maldives } \\
2008\end{array}$ & Current & $\begin{array}{l}\text { Article 64: No employee of the State shall impose any orders } \\
\text { on a person except under authority of a law. Everyone has the } \\
\text { right not to obey an unlawful order. } \\
\text { Article } 245 \text { : No person shall give an illegal order to a member } \\
\text { of the security services. Members of the security services shall } \\
\text { not obey a manifestly illegal order. }\end{array}$ \\
\hline Mali 1992 & Current & $\begin{array}{l}\text { Article 121: The foundation for every power of the Republic } \\
\text { of Mali resides in the Constitution. The republican form of } \\
\text { the State may not be revised. The people have the right to } \\
\text { civil disobedience in order to preserve the republican form of } \\
\text { the State. Any coup d'Etat or putsch is a crime against the } \\
\text { Malian People. }\end{array}$ \\
\hline
\end{tabular}




\begin{tabular}{|c|c|l|}
\hline Adopted & $\begin{array}{c}\text { Lasted } \\
\text { Until }\end{array}$ & \multicolumn{1}{c|}{ Full Text of the Relevant Provision(s) } \\
\hline $\begin{array}{c}\text { Mexico } \\
1814\end{array}$ & 1917 & $\begin{array}{l}\text { Article 14: . . undeniable popular right .. . establish . . . alter, } \\
\text { modify, or completely abolish the government, whenever nec- } \\
\text { essary for the people's happiness. }\end{array}$ \\
\hline $\begin{array}{c}\text { Mexico } \\
1917\end{array}$ & Current & $\begin{array}{l}\text { Article 136: This Constitution shall not lose its force and ef- } \\
\text { fect, even it [sic] its observance is interrupted by rebellion. In } \\
\text { the event that a government whose principles are contrary to } \\
\text { those that are sanctioned herein should become established } \\
\text { through any public disturbance, as soon as the people recover } \\
\text { their liberty, its observance shall be reestablished, and those } \\
\text { who have taken part in the government emanating from the } \\
\text { rebellion, as well as those who have cooperated with such persons, } \\
\text { shall be judged in accordance with this Constitution and the } \\
\text { laws that have been enacted by virtue thereof. }\end{array}$ \\
\hline Mozambique \\
1990 & Current & $\begin{array}{l}\text { Article 80: All citizens shall have the right not to comply with } \\
\text { orders that are unlawful or that infringe on their rights, free- } \\
\text { doms and guarantees. }\end{array}$ \\
\hline 1992 & 1996 & $\begin{array}{l}\text { Article 6: The people shall have the right and duty to resist an } \\
\text { oppressive regime through civil disobedience. Any regime that } \\
\text { deliberately violates the carrying out of this present Constitution } \\
\text { shall be considered an oppressive regime. The people shall } \\
\text { have the right to defend the established democratic regime } \\
\text { against a coup d'etat through civil disobedience. Civil disobe- } \\
\text { dience shall be exercised peacefully and only as a last resort. }\end{array}$ \\
\hline
\end{tabular}




\begin{tabular}{|c|c|l|}
\hline Adopted & $\begin{array}{c}\text { Lasted } \\
\text { Until }\end{array}$ & \multicolumn{1}{c|}{ Full Text of the Relevant Provision(s) } \\
\hline Paraguay & Current & $\begin{array}{l}\text { Article 138: (1) Citizens are hereby authorized to resist usurp- } \\
\text { ers through every means available to them. If a person or a } \\
\text { group of persons, acting in the name of any principle or repre- } \\
\text { sentation contrary to this Constitution, was to seize public } \\
\text { power, their action will be null, nonbinding, and of no value, } \\
\text { and therefore, exercising their right to resist oppression, the } \\
\text { people will be excused from having to comply with such ac- } \\
\text { tions. (2) Those foreign states that, under any circumstance, } \\
\text { cooperate with such usurpers will not be able to demand com- } \\
\text { pliance with any pact, treaty, or agreement signed with or } \\
\text { authorized by an usurping government as if these were obli- } \\
\text { gations or commitments of the Republic of Paraguay. }\end{array}$ \\
\hline Peru 1979 & 1993 & $\begin{array}{l}\text { Article 82: No one owes obedience to a usurping government } \\
\text { nor to anyone who may assume public functions or positions } \\
\text { in violation of the procedures which the Constitution and the } \\
\text { laws establish. The decrees of any usurped authority are void. } \\
\text { The people have the right to rise in insurrection in defense of } \\
\text { the constitutional order. }\end{array}$ \\
\hline Peru 1993
\end{tabular}




\begin{tabular}{|c|c|c|}
\hline Adopted & $\begin{array}{c}\text { Lasted } \\
\text { Until }\end{array}$ & Full Text of the Relevant Provision(s) \\
\hline $\begin{array}{c}\text { Portugal } \\
1976\end{array}$ & 1982 & $\begin{array}{l}\text { Article 7: (3) Portugal recognizes the right of all peoples to re- } \\
\text { volt against all forms of oppression.... } \\
\text { Article 20: (1) Everyone shall have access to the courts for the } \\
\text { defense of his rights. Justice shall not be withheld from a person } \\
\text { for lack of financial means. (2) Everyone shall have the right } \\
\text { to resist any order that infringes his rights, freedoms or safeguards } \\
\text { and to repel by force any form of aggression when recourse to } \\
\text { public authority is impossible. }\end{array}$ \\
\hline $\begin{array}{c}\text { Portugal } \\
1989\end{array}$ & Current & $\begin{array}{l}\text { Article 7: (3) Portugal recognizes the right of peoples to revolt } \\
\text { against all forms of oppression. } \\
\text { Article 21: Everyone shall have the right to resist any order that } \\
\text { infringes his rights, freedoms or safeguards and to repel by force } \\
\text { any form of aggression when recourse to public authority is } \\
\text { impossible. }\end{array}$ \\
\hline $\begin{array}{c}\text { Rwanda } \\
2003\end{array}$ & Current & $\begin{array}{l}\text { Article } 48 \text { : In all circumstances, every citizen, whether civilian } \\
\text { or military, has the duty to respect the Constitution, other laws } \\
\text { and regulations of the country. Every citizen has the right to } \\
\text { defy orders received from his or her superior authority if the } \\
\text { orders constitute a serious and manifest violation of human } \\
\text { rights and public freedoms. }\end{array}$ \\
\hline $\begin{array}{c}\text { Slovakia } \\
1992\end{array}$ & Current & $\begin{array}{l}\text { Article 32: Citizens have the right to put up resistance to } \\
\text { anyone who would eliminate the democratic order of human } \\
\text { rights and basic liberties listed in this Constitution, if the acti- } \\
\text { vity of constitutional bodies and the effective use of legal means } \\
\text { are rendered impossible. }\end{array}$ \\
\hline $\begin{array}{c}\text { Thailand } \\
2007\end{array}$ & Current & $\begin{array}{l}\text { Section 69: A person shall have the right to resist peacefully } \\
\text { any act committed for the acquisition of the power to rule the } \\
\text { country by a means which is not in accordance with the modes } \\
\text { provided in this Constitution. }\end{array}$ \\
\hline
\end{tabular}




\begin{tabular}{|c|c|c|}
\hline Adopted & $\begin{array}{c}\text { Lasted } \\
\text { Until }\end{array}$ & Full Text of the Relevant Provision(s) \\
\hline $\begin{array}{l}\text { Timor } \\
\text { L'este } \\
2002\end{array}$ & Current & $\begin{array}{l}\text { Article 2: (3) The validity of the laws and other actions of the } \\
\text { State depend upon their compliance with the Constitution. } \\
\text { Section 28: (1) All citizens have the right to disobey and to re- } \\
\text { sist illegal orders or orders that affect their fundamental rights, } \\
\text { freedoms and guarantees. (2) The right to self-defense is guar- } \\
\text { anteed to all, in accordance with the law. }\end{array}$ \\
\hline $\begin{array}{l}\text { Togo } \\
1992\end{array}$ & Current & $\begin{array}{l}\text { Article 45: All citizens have the duty to combat any person or } \\
\text { group of persons who would try to change by force the demo- } \\
\text { cratic order established by this Constitution. } \\
\text { Article 150: In case of a coup d'etat or other forcible coup, all } \\
\text { members of the government and of the National Assembly } \\
\text { shall have the right and the duty to take any and all means to } \\
\text { reestablish constitutional legitimacy. As a recourse, they may } \\
\text { call upon any existing agreements of military or defense coop- } \\
\text { eration. Under these circumstances, the duty of all Togolese } \\
\text { to disobey and to organize themselves to check any illegiti- } \\
\text { mate power shall be their most sacred right and their most im- } \\
\text { perative duty. Any overturning of the constitutional regime } \\
\text { shall be considered an indefeasible crime against the nation, } \\
\text { to be penalized according to laws of the Republic. }\end{array}$ \\
\hline
\end{tabular}




\begin{tabular}{|c|c|c|}
\hline Adopted & $\begin{array}{c}\text { Lasted } \\
\text { Until }\end{array}$ & \multicolumn{1}{c|}{ Full Text of the Relevant Provision(s) } \\
\hline Turkey & 1982 & $\begin{array}{l}\text { Preamble: } \text { Having enjoyed freedom, and fought for her rights } \\
\text { and liberties throughout her history, and having achieved the } \\
\text { Revolution of May 27, } 1960 \text { by exercising her right to resist } \\
\text { the oppression of a political power which had deteriorated into } \\
\text { a state of illegitimacy through behavior and actions contrary } \\
\text { to the rule of law and the Constitution, the Turkish Nation, } \\
\text { prompted and inspired by the spirit of Turkish nationalism, } \\
\text { which unites all individuals, be it in fate, pride or distress, in a } \\
\text { common bond as an indivisible whole around national con- } \\
\text { sciousness and aspirations, and which has as its aim always to } \\
\text { exalt our nation in a spirit of national unity as a respected } \\
\text { member of the community of the world of nations enjoying } \\
\text { equal rights and privileges; With full dedication to the prin- } \\
\text { ciple of "peace at home, peace in the world" and with full } \\
\text { dedication to the spirit of national independence, and sov- } \\
\text { ereignty and to the reforms of Atatür; Guided by the desire } \\
\text { to establish a democratic rule of law based on juridical and so- } \\
\text { cial foundations, which will ensure and guarantee human rights } \\
\text { and liberties, national solidarity, social justice, and the wel- } \\
\text { fare and prosperity of the individual and society; Now therefore, } \\
\text { the Turkish Nation hereby enacts and proclaims this Constitution } \\
\text { drafted by the Constituent Assembly of the Turkish Republic, } \\
\text { and entrusts it to the vigilance of her sons and daughters who } \\
\text { are devoted to the concepts of freedom, justice and integrity, } \\
\text { with the conviction that its basic guarantee lies in the hearts } \\
\text { and minds of her citizens. }\end{array}$ \\
\hline
\end{tabular}




\begin{tabular}{|c|c|l|}
\hline Adopted & $\begin{array}{c}\text { Lasted } \\
\text { Until }\end{array}$ & \multicolumn{1}{|c|}{ Full Text of the Relevant Provision(s) } \\
\hline $\begin{array}{c}\text { Uganda } \\
1995\end{array}$ & Current \\
1828 \\
Argentina, \\
Bolivia) \\
of Rio de
\end{tabular}




\begin{tabular}{|c|c|c|}
\hline Adopted & $\begin{array}{c}\text { Lasted } \\
\text { Until }\end{array}$ & Full Text of the Relevant Provision(s) \\
\hline $\begin{array}{c}\text { Uruguay } \\
1830\end{array}$ & Current & $\begin{array}{l}\text { Article 130: The inhabitants of the State are entitled to be pro- } \\
\text { tected in the enjoyment of their life, honor, freedom, security } \\
\text { and property. No one can be deprived of these rights, but ac- } \\
\text { cording to law. } \\
\text { Article 134: No inhabitant of the state will be forced to do } \\
\text { what the law does not require, nor prevented from doing what } \\
\text { it is [sic] not prohibited. }\end{array}$ \\
\hline $\begin{array}{c}\text { Venezuela } \\
1961\end{array}$ & 1999 & $\begin{array}{l}\text { Article 250: This Constitution shall not lose its effect even if } \\
\text { its observance is interrupted by force or it is repealed by means } \\
\text { other than those provided herein. In such eventuality, every } \\
\text { citizen, whether or not vested with authority, has the duty to } \\
\text { collaborate in the reestablishment of its effective validity. } \\
\text { Those who are found responsible for the acts indicated in the } \\
\text { first part of the preceding paragraph and also the principal of- } \\
\text { ficials of governments subsequently organized shall be judged } \\
\text { in accordance with this Constitution itself and laws enacted in } \\
\text { conformity therewith, if they have not contributed to the rees- } \\
\text { tablishment of its force and effect. Congress may decree, by } \\
\text { resolution approved by an absolute majority of its member, } \\
\text { the confiscation of all or a part of the property of such persons } \\
\text { and of those who have been unlawfully enriched under the } \\
\text { protection of usurpation, in order to reimburse the Republic } \\
\text { for damages incurred by it. }\end{array}$ \\
\hline $\begin{array}{c}\text { Venezuela } \\
1999\end{array}$ & Current & $\begin{array}{l}\text { Article 333: This Constitution shall not cease to be in effect if } \\
\text { it ceases to be observed due to acts of force or because or [sic] } \\
\text { repeal in any manner other than as provided for herein. In } \\
\text { such eventuality, every citizen, whether or not vested with of- } \\
\text { ficial authority, has a duty to assist in bringing it back into ac- } \\
\text { tual effect. } \\
\text { Article 350: The people of Venezuela, true to their republican } \\
\text { tradition and their struggle for independence, peace and free- } \\
\text { dom, shall disown any regime, legislation or authority that } \\
\text { violates democratic values, principles and guarantees or en- } \\
\text { croaches upon human rights. }\end{array}$ \\
\hline
\end{tabular}




\section{APPENDIXII: FULL REGRESSION RESULTS}

\begin{tabular}{|c|c|c|c|}
\hline & $\begin{array}{c}(1) \\
\text { Full Sample } \\
\end{array}$ & $\begin{array}{c}\text { (2) } \\
\text { Latin America }\end{array}$ & $\begin{array}{c}\text { (3) } \\
\text { Rest of World }\end{array}$ \\
\hline Coup in Last Four Years & $\begin{array}{c}0.00862^{* *} \\
(0.000) \\
\end{array}$ & $\begin{array}{c}0.02240^{* * * *} \\
(0.007)\end{array}$ & $\begin{array}{c}-0.00063 \\
(0.004) \\
\end{array}$ \\
\hline $\begin{array}{c}\text { Democratic Transition } \\
\text { in Last Four Years }\end{array}$ & $\begin{array}{c}0.01540^{* * * *} \\
(0.006)\end{array}$ & $\begin{array}{c}0.01970^{*} \\
(0.010) \\
\end{array}$ & $\begin{array}{c}0.01430^{\text {*** }} \\
(0.007) \\
\end{array}$ \\
\hline Democracy & $\begin{array}{c}0.00060^{* *} \\
(0.000)\end{array}$ & $\begin{array}{c}0.00062 \\
(0.001) \\
\end{array}$ & $\begin{array}{c}0.00064^{*} \\
(0.000) \\
\end{array}$ \\
\hline Energy Consumption & $\begin{array}{r}0.00000 \\
(0.000) \\
\end{array}$ & $\begin{array}{c}0.00493^{* * * *} \\
(0.002) \\
\end{array}$ & $\begin{array}{c}0.00000 \\
(0.000) \\
\end{array}$ \\
\hline Global Adoption $(t-1)$ & $\begin{array}{c}-0.16500^{* *} \\
(0.064) \\
\end{array}$ & $\begin{array}{c}-0.31700^{*} \\
(0.173)\end{array}$ & $\begin{array}{c}-0.09630 \\
(0.061) \\
\end{array}$ \\
\hline Regional Adoption $(t-1)$ & $\begin{array}{r}0.01690 \\
(0.028) \\
\end{array}$ & $\begin{array}{c}-0.07110 \\
(0.125) \\
\end{array}$ & $\begin{array}{c}0.01790 \\
(0.029) \\
\end{array}$ \\
\hline Coups Thus Far & $\begin{array}{c}0.00159^{\text {**** }} \\
(0.001) \\
\end{array}$ & $\begin{array}{c}0.00081 \\
(0.001) \\
\end{array}$ & $\begin{array}{c}0.00244^{*} \\
(0.001) \\
\end{array}$ \\
\hline Fixed Effects & Yes & Yes & Yes \\
\hline Time Trends & Yes & Yes & Yes \\
\hline Observations & 8176 & 1722 & 6158 \\
\hline $\mathrm{R}$-squared & 0.058 & 0.062 & 0.065 \\
\hline
\end{tabular}

Reported results are based on a fixed effects linear probability model. Robust standard errors clustered at the country level are reported in parentheses ${ }^{* * *} \mathrm{p}<0.01,{ }^{* *} \mathrm{p}<0.05$, ${ }^{*} \mathrm{p}<0.10$. 